\title{
REFLEXÕES SOBRE O ENSINO DO SISTEMA DE ESCRITA ALFABÉTICA EM DOCUMENTOS CURRICULARES: IMPLICAÇÕES PARA A FORMAÇÃO DE PROFESSORES
}

\author{
Leal Ferraz Telma \\ Universidade Federal de Pernambuco
}

Ana Carolina Perrusi Brandão

Universidade Federal de Pernambuco

Fabiana Belo dos Santos Almeida

Universidade Federal de Pernambuco

Erika Souza Vieira

Universidade Federal de Pernambuco

\section{Resumo}

$\mathrm{O}$ artigo objetiva refletir sobre a alfabetização como direito das crianças brasileiras. Na primeira parte, há uma reflexão sobre diferentes dimensões relativas ao ensino da leitura e da escrita no primeiro ciclo do Ensino Fundamental: (1) Apropriação do Sistema de Escrita Alfabética; (2) Desenvolvimento de habilidades/capacidades de produção e compreensão de textos orais e escritos: (3) Inserção em práticas sociais diversas, com base no trabalho de produção, compreensão e reflexão sobre gêneros textuais variados; (4) Reflexão sobre temáticas relevantes por meio dos textos. Na segunda parte, são expostos dados de uma pesquisa que tratou do ensino do sistema de escrita alfabética, por meio da análise de documentos curriculares brasileiros, com base na qual conclui-se que o ensino do sistema de escrita é contemplado nas propostas curriculares, mas há diferentes tendências quanto às concepções acerca de como tal aprendizagem deve ocorrer. No artigo, defende-se a terceira tendência: alfabetização na perspectiva do letramento. Por fim, na última parte do artigo, são realizadas reflexões acerca das convergências entre a abordagem da alfabetização na perspectiva do letramento e a proposta de formação de professores presente no Programa Pacto Nacional pela Alfabetização na Idade Certa, do Governo Federal.

Palavras-chave: Alfabetização; Letramento; Pacto Nacional; Formação de professores. 


\title{
REFLECTIONS ABOUT TEACHING THE ALPHABETIC WRITING SYSTEM IN OFFICIAL CURRICULUM DOCUMENTS AND ITS IMPLICATIONS FOR TEACHER TRAINING
}

\begin{abstract}
The article aims to look into the alphabetization as Brazilian children right. In the first part there is a reflection on different dimensions concerned to the teaching of reading and writing in the first cycle of primary school: (1) Appropriation of the Alphabetical Written System; (2) Development of oral and written text understanding abilities/capabilities; (3) Insertion in a variety of social practices, based on work with production, understanding and reflection on several textual genres; (4) Reflection on important themes through texts. In the second part, it is showed data of a research which has dealt with the teaching of Alphabetical Written System, through the analysis of Brazilian curriculum documents, based on which it has been concluded that the teaching of written system is dealt with in the curriculum proposals, nevertheless there are different trends related to how learning should take place. In the article, we have leaned toward the third trend: alphabetization in the literacy perspective. Finally, in the last part of the article, it has been made some reflection on the convergences between the approach of alphabetization in the perspective of literacy and the teacher formation proposal stated by the "National Agreement for the Alphabetization in the Write Age", of the Federal Government.
\end{abstract}

Keywords: Alphabetization; Literacy, PNAIC, Teacher Training. 
Reflexões sobre o ensino do sistema de escrita alfabética em documentos curriculares: implicações para a formação de professores

\section{Introdução}

A discussão em torno do tema alfabetização atrai pessoas de diferentes perfis profissionais e posições na sociedade. Frequentemente, ouvimos opiniões em jornais, revistas, televisão e outros veículos da mídia apontando o fracasso da escola brasileira nas diferentes etapas de escolaridade. No entanto, raramente esses mesmos veículos promovem debates mais aprofundados em que seja possível discutir e refletir sobre os parâmetros que podemos adotar para dizer que existe sucesso ou fracasso na escola, em especial, nos anos iniciais do Ensino Fundamental.

A esse respeito podemos, inicialmente, indagar: há parâmetros universais que possam definir o sucesso ou fracasso na educação? Quem irá atestar que a educação é "de qualidade"? As instituições financeiras internacionais? As empresas que vendem os materiais didáticos? O mercado de trabalho? Os pesquisadores da área? O Ministério da Educação? As equipes de gestão das secretarias de educação? Os profissionais da escola? As comunidades onde as escolas estão inseridas?

Certamente, todos esses segmentos estabelecem seus próprios parâmetros de qualidade e, evidentemente, há tensões entre eles e no interior de cada um. Por tal motivo, o currículo em ação, elemento básico no conceito de qualidade, se dá por meio de conflitos e negociações constantes, seja entre as agências de produção de materiais e de formação docente públicas e as privadas, seja no âmbito das instituições formadoras e de pesquisa, entre pesquisadores que teorizam sobre currículo e pesquisadores das áreas de conhecimentos de conteúdos específicos, entre pesquisadores que adotam diferentes matrizes teóricas, entre instituições formadoras e secretarias de educação, entre Ministério da Educação e secretarias de educação, entre secretarias de educação e unidades escolares, entre unidades escolares e comunidades locais. 
Em meio a todas essas tensões, os professores, nas escolas, constroem alguns consensos para viabilizar as ações cotidianas e criam estratégias para contornar os limites impostos. Nesse sentido, assim como Moreira e Candau (2007, p. 18), entendemos o currículo:

Como as experiências escolares que se desdobram em torno do conhecimento, em meio a relações sociais, e que contribuem para a construção das identidades de nossos/as estudantes. Currículo associase, assim, ao conjunto de esforços pedagógicos desenvolvidos com intenções educativas.

No entanto, reconhecemos a existência de diferentes intenções, articuladas às diferentes concepções sobre o que seria uma escola de qualidade que, por sua vez, são atreladas às concepções sobre o papel da escola e sobre as relações entre escola e outras esferas sociais de interação.

Um aspecto fundamental a guiar as reflexões sobre sucesso ou fracasso escolar é que não só os conhecimentos são apropriados no contexto escolar, mas também são reafirmados ou construídos valores e sentimentos. Santos, Lucíola e Paraíso (1996, p. 37), a esse respeito, afirmam que: "o currículo constrói identidades e subjetividades: junto com os conteúdos das disciplinas escolares, adquirem-se na escola percepções, disposições e valores que orientam os comportamentos e estruturam as personalidades". Assumimos, assim, que a escola tem papel importante, na sociedade atual, de colaborar para o desenvolvimento integral dos estudantes, fortalecendo suas identidades sociais e sua inserção em diferentes esferas de interlocução. Desse modo, consideramos que, para ter sucesso, a escola precisa ser concebida como:

* um espaço de apropriação de conhecimentos sobre o mundo físico e social;

* uma esfera de interlocução que inclui a finalidade de gerar situações 
Reflexões sobre o ensino do sistema de escrita alfabética em documentos curriculares: implicações para a formação de professores

que favoreçam os processos de ensino e aprendizagem dos conceitos construídos pelo mundo da ciência, ao mesmo tempo que se constitui um lócus de desenvolvimento pessoal e social, em que se difundem valores e princípios de convivência;

* um ambiente em que se pensa sobre as relações com a natureza, com o outro e consigo mesmo;

* uma instituição que pode promover a socialização dos instrumentos de compreensão e de transformação da realidade;

* um espaço de construção e defesa de valores sociais, na perspectiva da inclusão; que pode promover o respeito às diferenças e a luta pelos direitos, planejando situações em que os estudantes participem de ações de combate aos preconceitos e atitudes discriminatórias (preconceito racial, de gênero, preconceito a grupos sexuais, preconceito linguístico, dentre outros).

Nessa perspectiva, a escola de sucesso é, portanto, a que desenvolve um currículo inclusivo, que rompe com os valores relativos à competitividade, ao individualismo, à busca de vantagens individuais e que fortalece identidades sociais nem sempre valorizadas em nossa sociedade. Ao assumirmos tais pressupostos gerais, não estamos, no entanto, negando que conhecimentos das diferentes áreas de conhecimento sejam relevantes. Ao contrário, consideramos que há conhecimentos que as sociedades letradas deste Século precisam garantir como direitos dos estudantes, como, por exemplo, o direito de ser alfabetizado. Discutiremos sobre esse tópico a seguir.

\section{Alfabetização como direito}

A defesa da alfabetização como direito é feita com base na ideia de que a linguagem:

- constitui identidades;

- possibilita o acesso a bens culturais construídos na sociedade letrada, incluindo o conjunto de conhecimentos relativos às diferentes esferas

Olh@res, Guarulhos, v. 1, n. 2, p. 69-99, Novembro, 2013. 
sociais (como a esfera científica, a esfera artística, a esfera midiática, a esfera da política, a esfera da religião, dentre outras);

- promove a inserção em diferentes situações de interação, constituindo-se como instrumento de ação social;

- possibilita o próprio processo de escolarização.

Desse modo, o ensino da oralidade e da escrita assume centralidade no processo educativo, sendo, portanto, o meio de constituir subjetividades, estabelecer interações e integrar conhecimentos oriundos de diferentes esferas de interlocução, sobretudo, as ligadas à arte e à ciência, incluindo, nesse segundo caso, as diferentes áreas de conhecimento.

Um outro motivo que justifica a defesa do ensino da oralidade e da escrita como direitos básicos no currículo escolar é a clareza de que há um conjunto de objetos culturais que são desigualmente distribuídos na sociedade, entre eles a escrita e seus diferentes suportes. Nesse sentido, pressupomos, assim como Araújo (1998, p. 94), que a apropriação da linguagem nos primeiros anos escolares deve: "possibilitar vivências com a leitura e a escrita que tenham relevância e significado para a vida da criança, algo que se torne uma necessidade para ela e que lhe permita refletir sobre sua realidade e compreendê-la".

Em suma, os princípios de um currículo inclusivo no ciclo de alfabetização englobam a definição de alguns conhecimentos e habilidades a serem apropriados por todos os estudantes, respeitandose as singularidades, diferenças individuais e de grupos sociais. Dessa forma, quatro dimensões importantes do processo de alfabetização podem ser salientadas: (1) Apropriação do Sistema de Escrita Alfabética; (2) Desenvolvimento de habilidades/capacidades de produção e compreensão de textos orais e escritos: (3) Inserção em práticas sociais diversas, com base no trabalho de produção, 
Reflexões sobre o ensino do sistema de escrita alfabética em documentos curriculares: implicações para a formação de professores

compreensão e reflexão sobre gêneros textuais variados; (4) Reflexão sobre temáticas relevantes por meio dos textos.

Neste artigo, dedicamo-nos a refletir sobre uma dessas dimensões: a apropriação do sistema de escrita alfabética, por considerarmos que só após tal domínio o indivíduo pode ter garantido seu direito de ler e produzir textos com autonomia em diferentes contextos da sociedade.

\section{A aprendizagem do sistema de escrita alfabética}

O ensino do sistema de escrita alfabética vem sendo praticado de maneiras muito variadas pelos docentes, refletindo distintas concepções de alfabetização. A esse respeito, Soares (2003) salienta duas tendências sobre o conceito de alfabetização:

$\mathrm{Ou}$ se atribui à alfabetização um conceito demasiado amplo (muitas vezes até mesmo ultrapassando os limites do mundo da escrita), ou, ao contrário, atribui-se a ela um conceito excessivamente restrito (a mera decodificação de fonemas e decodificação de grafemas). (...) no primeiro caso, a qualidade da alfabetização é constituída de tão numerosos e variados atributos, que ela, sendo tudo, torna-se nada; no segundo caso, a qualidade da alfabetização é constituída de tão limitados e modestos atributos que ela, sendo pouco, torna-se também nada (SOARES, 2003, p. 53).

Como se vê, para essa autora, na medida em que se nega a especificidade de conhecimentos relativos à aprendizagem do sistema de escrita pode-se inibir ou pelo menos adiar a existência, na prática docente, de situações favoráveis à aprendizagem da língua. Para Soares (2003), a escola, para a maioria das crianças, é o espaço privilegiado onde tal aprendizagem - a do sistema de escrita - ocorre, embora a ampliação das aprendizagens ocorra não apenas nesse ambiente. 
Concebemos, na verdade, que não apenas o mundo da escola, mas o mundo do lazer, o mundo da religião, o mundo do trabalho, dentre outros, impõem a necessidade de novas aprendizagens e ampliação de habilidades de leitura, de escrita e de oralidade diversas, mas a escola é uma importante esfera social onde tais aprendizagens ocorrem de modo mais sistemático.

Concebemos a alfabetização como um processo em que as crianças possam aprender como é o funcionamento do sistema de escrita (relacionar unidades gráficas, as letras individualmente ou os dígrafos, às unidades sonoras, os fonemas), de modo articulado e simultâneo às aprendizagens relativas aos usos sociais da escrita e da oralidade.

Com relação às aprendizagens relativas ao funcionamento do sistema de escrita, há uma série de conhecimentos que devem ser garantidos aos estudantes, tal como especificados por Leal e Morais (2010, p. 3536). São eles:

1. Escreve-se com letras que não podem ser inventadas, que têm um repertório finito e que são diferentes de números e de outros símbolos.

2. As letras têm formatos fixos e pequenas variações produzem mudanças em sua identidade ( $, \mathrm{q}, \mathrm{b}, \mathrm{d})$, embora uma letra assuma formatos variados $(\mathrm{P}, \mathrm{p}, P, p)$.

3. A ordem das letras no interior da palavra não pode ser mudada.

4. Uma letra pode se repetir no interior de uma palavra e em diferentes palavras, ao mesmo tempo em que distintas palavras compartilham as mesmas letras.

5. Nem todas as letras podem ocupar certas posições no interior das palavras e nem todas as letras podem vir juntas de quaisquer outras.

6. As letras notam ou substituem a pauta sonora das palavras que pronunciamos e nunca levam em conta as características físicas ou funcionais dos referentes que substituem.

7. As letras notam segmentos sonoros menores que as sílabas orais que pronunciamos.

8. As letras têm valores sonoros fixos, apesar de muitas terem mais de um valor sonoro e certos sons poderem ser notados com mais de uma letra.

9. Além de letras, na escrita de palavras, usam-se, também, algumas marcas (acentos) que podem modificar a tonicidade ou o som das letras ou sílabas onde aparecem.

10. As sílabas podem variar quanto às combinações entre consoantes e vogais $(\mathrm{CV}$, $\mathrm{CCV}, \mathrm{CVV}, \mathrm{CVC}, \mathrm{V}, \mathrm{VC}, \mathrm{VCC}, \mathrm{CCVCC} .$. ), mas a estrutura predominante no português é a sílaba CV (consoante - vogal), e todas as sílabas do português contêm, ao menos, uma vogal.

Vale frisar que ao se defender que tais conhecimentos sejam adquiridos no ciclo de alfabetização, não se está minimizando o papel 
Reflexões sobre o ensino do sistema de escrita alfabética em documentos curriculares: implicações para a formação de professores

da aprendizagem de capacidades de produção e de compreensão de textos orais e escritos. Ao contrário, adotando o conceito de alfabetização explicitado acima, entendemos que o trabalho pedagógico voltado a esse tópico deve ser iniciado na Educação Infantil, continuando durante todo o percurso escolar com base em objetivos de ensino claros definidos para cada etapa.

Vê-se, portanto, que a alfabetização é um processo longo e complexo e como tal há até hoje um grande debate entre diferentes propostas sobre o ensino da base alfabética, um dos focos do presente artigo. $\mathrm{Na}$ seção seguinte, buscamos apresentar, de modo breve, diferentes tendências acerca do ensino da base alfabética.

\subsection{Alfabetização: tendências de ontem e de hoje...}

Os estudos sobre os métodos de alfabetização apontam três grandes agrupamentos de perspectivas: abordagens sintéticas, analíticas e analítico-sintéticas. Tais denominações foram inicialmente propostas na "XII Conferência Internacional sobre a Aprendizagem da Leitura e da Escrita", organizada pela UNESCO e pelo Bureau International d'Education, em Genéve, em 1949.

Os chamados "métodos sintéticos" preveem o início da aprendizagem a partir dos elementos estruturalmente mais simples da linguagem escrita, ou seja, das unidades linguísticas menores (letras ou sílabas) para as unidades maiores (palavras, frases e textos). A origem desses métodos pode ser encontrada em escritos de Mialaret (1967) e Matthews (1966), que indicam que os métodos alfabéticos foram utilizados desde a antiga Grécia e o Império Romano. Tais métodos sofreram, ao longo da história, várias transformações. Nos dias atuais uma das abordagens sintéticas mais conhecidas é a dos "Métodos fônicos". A unidade inicial de ensino, nessa abordagem, não é a letra ou a sílaba, mas, sim as unidades sonoras mínimas - os fonemas. Nos métodos fônicos parte-se do pressuposto de que cada letra dispõe de certa autonomia fonética e se baseia nas intuições

Olh@res, Guarulhos, v. 1, n. 2, p. 69-99, Novembro, 2013. 
fonéticas da criança, e em sua capacidade de imitação de sons específicos. Basicamente, trata-se de fazer segmentar os fonemas, além de outras atividades de reflexão fonológica, seguida da aprendizagem das letras que representam tais fonemas.

Dentre as inúmeras críticas aos métodos sintéticos, é frequente a de que tal abordagem desconsidera que a criança é um aprendiz ativo, que busca compreender as regularidades da escrita e entender seus princípios de funcionamento.

O segundo agrupamento citado contempla os métodos analíticos. Nesses, as unidades mínimas significativas da língua (palavras ou frases) são tomadas como objeto de ensino, por meio de memorização e posterior trabalho de ajuste do sonoro ao escrito. Assim, os adeptos do método analítico entendem que a criança não reconhece que as letras representam unidades de sons, de forma que o inteiro conjunto de letras é ensinado em sua totalidade como se representasse uma palavra específica (Decroly, Degand, 1906; Dottrens, Margairaz, 1951; Mialaret, 1967).

Uma das principais críticas a tal abordagem é a de que a criança é exposta a situações de memorização, que tornam o ensino um processo monótono e mecânico. Além disso, apesar da preocupação em inserir o estudante no ensino por meio do acesso a unidades "significativas", os textos e as palavras não estão, de fato, inseridos em situações de interação mediadas por textos de circulação social.

Os métodos analítico-sintéticos, que compõem o terceiro agrupamento mencionado, privilegiam os aspectos cognitivos na aprendizagem da leitura, com ênfase nos processos de composição e decomposição de palavras. Em geral, inicia-se com atividades de reconhecimento de palavras, que são decompostas e comparadas a outras palavras, com atividades de reconhecimento do valor fônico e gráfico.

Olh@res, Guarulhos, v. 1, n. 2, p. 69-99, Novembro, 2013. 
Reflexões sobre o ensino do sistema de escrita alfabética em documentos curriculares: implicações para a formação de professores

Trabalhos de autores como Smith e Goodman (Goodman, 1967; Smith, 1971, 1973), Giséle Prefontaine (1969), Skinner \& Correl (1974), Kratzmeier (1971) e Sullivan (1986) ilustram tal perspectiva. A crítica feita a esses métodos é a de que, tal como os anteriores, também não se considera a dimensão do letramento no processo de ensino e aprendizagem da língua escrita. Além disso, não dão conta de explicar os processos que levam o aprendiz a compreender o funcionamento do sistema de escrita.

Em decorrência dessa lacuna, podemos entender porque os estudos de Ferreiro e Teberosky (1979) foram tão significativos no final do século passado. Diferentemente das abordagens tratadas até aqui, os conhecimentos informais que a criança desenvolve acerca da escrita fora da escola passam a ser considerados, sendo valorizadas as suas tentativas de entender seu funcionamento. Surgem, então, propostas de alfabetização baseadas em concepções sobre o ensino da língua inspiradas nas abordagens construtivistas. Nessas propostas, defendese que as crianças "descobrem" as convenções e princípios do sistema alfabético por si mesmas e ao professor cabe atuar como um facilitador no processo de aprendizagem, provocando desequilíbrios cognitivos que impulsionariam a aprendizagem.

$\mathrm{Na}$ classificação das tendências relativas ao ensino da leitura e da escrita, podemos ainda citar abordagens oriundas da abordagem sociointeracionista. Nesse caso, a ideia central é que a alfabetização se dá na interação entre sujeitos ativos que, imersos nas situações de leitura e produção de textos, tornam-se usuários do sistema de escrita. Desse modo, para alguns seguidores dessa perspectiva, não seria necessário conduzir ensino mais sistemático dos conhecimentos que compõem o sistema de escrita, pois o próprio contato com os textos, em situação de interação garantiriam tais aprendizagens.

Uma outra abordagem também pautada na concepção sociointeracionista da língua é a proposta da alfabetização na perspectiva do letramento. Nesse caso, enfatiza-se a participação do aprendiz em práticas sociais mediadas por textos escritos.

Olh@res, Guarulhos, v. 1, n. 2, p. 69-99, Novembro, 2013. 
Considera-se que por meio dessas práticas, as crianças se apropriariam do sistema alfabético de escrita, refletindo sobre suas convenções e princípios a partir da mediação do professor.

Considerando as tendências expostas nessa seção, buscamos analisar como documentos oficiais recentes das secretarias municipais e estaduais brasileiras concebem o ensino do sistema de escrita alfabética.

\section{O ensino do sistema de escrita alfabética em documentos curriculares}

A pesquisa cujo resultado passaremos a apresentar nesta seção se desenvolveu por meio de análise documental com base na proposta de Bardin (2007). Foram analisados 26 documentos curriculares do Ensino Fundamental, sendo 12 de secretarias municipais de capitais brasileiras e 14 de secretarias estaduais elaborados ou reformulados na primeira década deste Século, conforme disposto abaixo:

\begin{tabular}{|l|l|l|}
\hline Região & Documentos municipais & Documentos estaduais \\
\hline Norte & Rio Branco & Amazonas, Rondônia \\
\hline Nordeste & Natal, Recife, Teresina & $\begin{array}{l}\text { Maranhão, Pernambuco, } \\
\text { Alagoas, Sergipe }\end{array}$ \\
\hline $\begin{array}{l}\text { Centro- } \\
\text { oeste }\end{array}$ & Campo Grande, Cuiabá & Goiás, Mato Grosso \\
\hline Sudeste & $\begin{array}{l}\text { Belo Horizonte, Rio de } \\
\text { Janeiro, São Paulo, Vitória }\end{array}$ & $\begin{array}{l}\text { Minas Gerais, Rio de } \\
\text { Janeiro, São Paulo, Espírito } \\
\text { Santo }\end{array}$ \\
\hline Sul & Florianópolis, Curitiba & Santa Catarina, Paraná \\
\hline
\end{tabular}

Como foi dito anteriormente, neste artigo enfocamos as orientações relativas ao ensino da base alfabética presentes nos documentos que, como também já afirmamos aqui, constitui uma das dimensões do ensino no ciclo de alfabetização. $\quad$ A análise dos documentos curriculares selecionados mostrou que todos eles contemplam orientações relativas ao ensino do sistema de 
Reflexões sobre o ensino do sistema de escrita alfabética em documentos curriculares: implicações para a formação de professores

escrita alfabética (doravante, SEA) desde o início do Ensino

Fundamental. No entanto, foram identificadas diferenças quanto à ênfase dada a tal conteúdo curricular, refletida no nível de explicitação dos princípios didáticos envolvidos no ensino desse sistema.

Assim, por exemplo, enquanto os documentos de Minas Gerais e de Campo Grande elencam de forma detalhada objetivos didáticos referentes à apropriação do SEA, os documentos do Mato Grosso e Cuiabá mencionam de modo mais genérico que "é preciso compreender o funcionamento do sistema de escrita alfabética". Vejamos alguns trechos do documento de Minas Gerais (2003) e de Mato Grosso (2011) que ilustram essa afirmação.

Um conhecimento fundamental que os alunos precisam adquirir no seu processo de alfabetização diz respeito à natureza da relação entre a escrita e a cadeia sonora das palavras que eles tentam escrever ou ler (MINAS GERAIS, 2003, pág: 31, Caderno 2- alfabetizando).

Quando se orienta a ação pedagógica para o letramento, não é necessário, nem recomendável, que, por isso, se descuide do trabalho específico com o sistema de escrita. Noutros termos: o fato de valorizar em sala de aula os usos e as funções sociais da língua escrita não implica deixar de tratar sistematicamente da dimensão especificamente linguística do "código", que envolve os aspectos fonéticos, fonológicos, morfológicos e sintáticos. Do mesmo modo, cuidar da dimensão lingüística, visando à alfabetização, não implica excluir da sala de aula o trabalho voltado para o letramento. Outra fonte de equívocos é pensar os dois processos como seqüenciais, isto é, vindo um depois do outro, como se o letramento fosse uma espécie de preparação para a alfabetização, ou, então, como se a alfabetização fosse condição indispensável para o início do processo de letramento" (MINAS GERAIS, 2003, pág. 13-14, Caderno 2 alfabetizando).

Com relação à alfabetização e ao letramento na perspectiva das linguagens, é imprescindível propor atividades que valorizem os conhecimentos e vivências dos estudantes e promovam um contato organizado e constante com os diferentes textos e leituras, possibilitando que a criança se aproprie, analise, compreenda e faça uso dos códigos no contexto sociocultural (MATO GROSSO, 2010 - pág. 16).

Na concepção psicogenética de alfabetização, a tecnologia da escrita é apreendida por meio de atividades de "letramento", ou seja, de leitura e produções de textos reais e de práticas sociais de leitura e escrita (MATO GROSSO, 2010 - pág. 17). 
Como foi anunciado, foram encontradas, entre os dois documentos citados, grandes diferenças quanto à ênfase dada ao ensino do SEA. Outras propostas curriculares também evidenciam tal diversidade. Considerando tais diferenças, buscamos melhor especificar quais conhecimentos / habilidades foram citados nos documentos. As categorias criadas com base nessa análise foram agrupadas em quatro blocos, a saber:

- Leitura e escrita do nome próprio e de outras palavras estáveis;

- Conhecimentos e habilidades relativas ao ensino das letras do alfabeto;

- Habilidades de consciência fonológica e relações entre unidades sonoras e representações gráficas;

- Conhecimentos e habilidades relacionados aos diferentes tipos de sílabas.

Com esse procedimento foi possível identificar o perfil das propostas curriculares analisadas no que se refere aos conhecimentos citados acima, sendo também possível constatar o quantitativo de documentos que contemplam as categorias formuladas. Nos itens seguintes apresentamos os principais resultados obtidos com essa análise, considerando os quatro blocos de análise mencionados acima.

\subsection{Leitura e escrita do próprio nome e de outras palavras estáveis}

Um tipo de orientação recorrente nos documentos foi o de que o professor deve realizar atividades de escrita do próprio nome e de outras palavras estáveis, ou seja, palavras que as crianças leiam globalmente, sem dominar ainda o funcionamento do sistema de escrita.

Como se pode ver na Tabela 1, a seguir, em treze (50\%) documentos registram-se orientações relativas ao trabalho com o nome das crianças, tanto em relação à escrita, quanto à leitura.

Olh@res, Guarulhos, v. 1, n. 2, p. 69-99, Novembro, 2013. 
Reflexões sobre o ensino do sistema de escrita alfabética em documentos curriculares: implicações para a formação de professores

Dez documentos $(38,5 \%)$ também explicitam a importância de favorecer o reconhecimento de outras palavras.

Tabela 1: Frequência e percentual de documentos que contemplam orientações de trabalho com palavras estáveis

\begin{tabular}{|l|c|c|c|c|}
\hline \multicolumn{1}{|c|}{ Categorias } & $\begin{array}{c}\text { Documentos } \\
\text { Municipais } \\
(12)\end{array}$ & $\begin{array}{c}\text { Documentos } \\
\text { Estaduais } \\
(14)\end{array}$ & Total & $\begin{array}{c}\text { Percentual } \\
(\%)\end{array}$ \\
\hline Ler e escrever seu próprio nome & 7 & 6 & 13 & $50,0 \%$ \\
\hline $\begin{array}{l}\text { Reconhecer e reproduzir por } \\
\text { escrito palavras estáveis, além } \\
\text { de seu próprio nome }\end{array}$ & 6 & 4 & 10 & $38,5 \%$ \\
\hline
\end{tabular}

Pudemos identificar que 14 documentos $(53,8 \%)$ contemplam pelo menos uma das duas categorias relativas a esse bloco de conhecimentos, tal como apresentado no Quadro 1, abaixo:

\section{Quadro 1: Identificação dos documentos que contemplam orientações para o trabalho com palavras estáveis ${ }^{1}$}

\begin{tabular}{|c|c|c|c|c|c|c|c|c|c|c|c|c|c|c|c|c|c|c|c|c|c|c|c|c|c|c|c|}
\hline \multicolumn{13}{|c|}{ Municípios } & \multicolumn{14}{|c|}{ Estados } & \multirow{3}{*}{ Total } \\
\hline \multirow[t]{2}{*}{1} & 2 & 3 & 4 & 5 & 6 & 7 & 8 & 9 & 1 & 1 & 1 & & & 1 & 1 & 1 & 1 & 1 & 1 & 2 & 2 & 2 & 2 & 2 & 2 & 2 & \\
\hline & & & & & & & & & 0 & 1 & 2 & & & 4 & 5 & 6 & 7 & 8 & 9 & 0 & 1 & 2 & 3 & 4 & 5 & 6 & \\
\hline \multicolumn{28}{|c|}{ Ler e escrever seu próprio nome } \\
\hline- & $\mathbf{X}$ & - & - & - & $\mathbf{X}$ & $\bar{X}$ & $\bar{X}$ & $\mathbf{X}$ & $X$ & 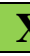 & - & & & $\mathbf{X}$ & 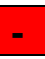 & $\mathbf{X}$ & $\mathbf{X}$ & - & $\mathbf{X}$ & - & - & X & - & - & $\mathbf{X}$ & - & 13 \\
\hline \multicolumn{28}{|c|}{ Reconhecer e reproduzir por escrito palavras estáveis, além de seu próprio nome } \\
\hline - & $\mathbf{X}$ & $\mathbf{X}$ & - & - & $\mathbf{X}$ & & - & $\mathrm{X}$ & $y$ & 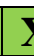 & . & & & - & - & $\mathbf{X}$ & $\mathbf{X}$ & - & $\mathbf{X}$ & - & - & $\mathrm{X}$ & - & - & - & - & 10 \\
\hline
\end{tabular}

Vale destacar que embora a construção de um repertório de palavras estáveis se relacione, de certa forma, com as propostas de métodos globais (ver Decroly, Degand, 1906; Dottrens, Margairaz, 1951; Mialaret, 1967), em que os aprendizes memorizam palavras ou sentenças, não se pode caracterizar os documentos nessa perspectiva.

\footnotetext{
${ }^{1}$ Neste Quadro e nos demais apresentados a seguir, os documentos foram numerados obedecendo sempre a seguinte ordem: 1 - Belo Horizonte; 2 - Campo Grande; 3 - Cuiabá; 4 - Curitiba; 5 - Florianópolis; 6 Natal; 7 - Recife; 8 - Rio Branco; 9 - Rio de Janeiro (capital); 10 - São Paulo (capital); 11 - Teresina; 12 Vitória; 13 - Alagoas; 14 - Amazonas; 15 - Espírito Santo; 16 - Goiás; 17 - Maranhão; 18 - Mato Grosso; 19 - Minas Gerais; 20 - Paraná; 21 - Pernambuco; 22 - Rio de Janeiro; 23 - Rondônia; 24 - Santa Catarina; 25 - São Paulo; 26 - Sergipe.
}

Olh@res, Guarulhos, v. 1, n. 2, p. 69-99, Novembro, 2013. 
Nos documentos analisados, o objetivo de tais atividades não é simplesmente o de que as crianças memorizem tais palavras, e sim, que possam utilizá-las em atividades reflexivas, tal como recomendado por Leal (2006):

No início da alfabetização, pode-se realizar atividades que os alunos aprendam um conjunto de palavras que possam servir de fontes de informações para a escrita de outras palavras. Por exemplo, se eles sabem os nomes deles, em atividades de leitura podem descobrir onde estão escritas determinadas palavras porque começam com o mesmo som (LEAL, 2006, p.95).

Como sabemos, os métodos globais propõem uma ordem fixa de palavras e sentenças a serem memorizadas. Tal memorização também não costuma ser seguida de atividades de reflexão acerca da lógica de construção dessas palavras e sentenças. Também, como já discutimos, não há uma preocupação do método com a inserção de textos de circulação social no processo de alfabetização. Desse modo, seria um reducionismo interpretar a recomendação para o trabalho com palavras estáveis como sinal de adoção de uma determinada perspectiva metodológica.

\subsection{Conhecimentos e habilidades relativas ao ensino das letras do} alfabeto

Como vimos anteriormente, sobretudo nos métodos sintéticos, partese da noção de que as crianças deveriam, primeiro, aprender as letras para depois aprender a "juntá-las" em sílabas e palavras (ver Mialaret, 1967; Matthews, 1966). Nessa perspectiva, o conhecimento das letras é tomado como pré-requisito para aprendizagens seguintes, assim como considera-se a necessidade de que elas sejam ensinadas numa certa ordem considerando critérios "linguísticos", tais como a maior ou menor dificuldade ortográfica que envolveria o uso dessas letras.

Olh@res, Guarulhos, v. 1, n. 2, p. 69-99, Novembro, 2013. 
Reflexões sobre o ensino do sistema de escrita alfabética em documentos curriculares: implicações para a formação de professores

Em uma abordagem da alfabetização na perspectiva do letramento, diferentemente das abordagens sintéticas, considera-se que o conhecimento das letras deve ocorrer de modo simultâneo às outras aprendizagens, sem ordem fixa de sua apresentação para as crianças. Assim, as letras são aprendidas no próprio processo de reflexão sobre o funcionamento da escrita e nas próprias práticas de leitura e produção de textos. Nesse sentido, autores como Leite (2006) e Albuquerque e Leite (2010) afirmam que esse é um dos conhecimentos a serem construídos ao longo do processo de alfabetização, desde a Educação Infantil.

Conforme pode ser observado na Tabela 2, onze tipos de orientações foram identificadas envolvendo conhecimento de letras. As orientações mais frequentes dizem respeito a "conhecer diferentes tipos de letras" (61,5\%); "diferenciar letras de outros símbolos" (57,7\%); “conhecer a ordem alfabética $(53,8 \%)$ e, finalmente, "reconhecer e nomear as letras $(46,1 \%)$.

Tabela 2: Frequência e percentual de documentos que contemplam orientações de trabalho com conhecimentos sobre as letras do alfabeto

\begin{tabular}{|l|c|c|c|c|}
\hline \multicolumn{1}{|c|}{ Categorias } & $\begin{array}{c}\text { Documentos } \\
\text { Municipais } \\
(12)\end{array}$ & $\begin{array}{c}\text { Documentos } \\
\text { Estaduais } \\
(14)\end{array}$ & Total & $\begin{array}{c}\text { Percentual } \\
(\%)\end{array}$ \\
\hline $\begin{array}{l}\text { Compreender que as palavras são escritas } \\
\text { com letras }\end{array}$ & 2 & 4 & 6 & $23,1 \%$ \\
\hline $\begin{array}{l}\text { Diferenciar as letras de outros símbolos } \\
\text { (numerais, sinais de pontuação, sinais de } \\
\text { trânsito, dentre outros). }\end{array}$ & 8 & 7 & 15 & $57,7 \%$ \\
\hline Reconhecer as letras, nomeando-as & 6 & 6 & 12 & $46,1 \%$ \\
\hline Grafar as letras do alfabeto & 4 & 3 & 7 & $26,9 \%$ \\
\hline Conhecer diferentes tipos de letras & 8 & 8 & 16 & $61,5 \%$ \\
\hline Conhecer a ordem alfabética & 7 & 7 & 14 & $53,8 \%$ \\
\hline $\begin{array}{l}\text { Reconhecer e nomear a letra inicial do } \\
\text { próprio nome e/ ou de outras palavras }\end{array}$ & 2 & 2 & 4 & $15,4 \%$ \\
\hline Escrever com letra de imprensa maiúscula & 6 & 2 & 8 & $30,8 \%$ \\
\hline Escrever com letra cursiva & 3 & 2 & 5 & $19,2 \%$ \\
\hline $\begin{array}{l}\text { Compreender que palavras diferentes } \\
\text { podem compartilhar algumas letras. }\end{array}$ & 2 & 3 & 5 & $19,2 \%$ \\
\hline $\begin{array}{l}\text { Compreender que as palavras diferem } \\
\text { quanto ao número de letras e/ou quanto ao } \\
\text { repertório e/ou ordem das mesmas. }\end{array}$ & 2 & 2 & 4 & $15,3 \%$ \\
\hline
\end{tabular}

Olh@res, Guarulhos, v. 1, n. 2, p. 69-99, Novembro, 2013. 
$\mathrm{Na}$ análise dos documentos curriculares, foi observado que 24 propostas (92,3\%, ver Quadro 2, abaixo) sinalizam a importância do conhecimento sobre as letras no processo de alfabetização, contemplando, no mínimo, um dos tipos de orientações, entre os nove elencados na Tabela 2.

Quadro 2: Identificação dos documentos que contemplam orientações para o trabalho com as letras do alfabeto

\begin{tabular}{|c|c|c|c|c|c|c|c|c|c|c|c|c|c|c|c|c|c|c|c|c|c|c|c|c|c|c|}
\hline \multicolumn{12}{|c|}{ Municípios } & \multicolumn{14}{|c|}{ Estados } & \multirow{3}{*}{ Total } \\
\hline \multirow[t]{2}{*}{1} & \multirow[t]{2}{*}{2} & \multirow[t]{2}{*}{3} & \multirow[t]{2}{*}{4} & \multirow[t]{2}{*}{5} & \multirow[t]{2}{*}{6} & \multirow[t]{2}{*}{7} & \multirow[t]{2}{*}{8} & \multirow[t]{2}{*}{9} & \multirow{2}{*}{\begin{tabular}{|l}
1 \\
0 \\
\end{tabular}} & 1 & \multirow{2}{*}{$\begin{array}{l}1 \\
2 \\
\end{array}$} & & \multirow{2}{*}{$\begin{array}{l}1 \\
4\end{array}$} & \multirow{2}{*}{\multicolumn{2}{|c|}{\begin{tabular}{|l|l|}
1 & 1 \\
5 & 6 \\
\end{tabular}}} & \multirow{2}{*}{$\begin{array}{l}1 \\
7\end{array}$} & \multirow{2}{*}{$\begin{array}{l}1 \\
8\end{array}$} & \multirow{2}{*}{$\begin{array}{l}1 \\
9 \\
\end{array}$} & \multirow{2}{*}{$\begin{array}{l}2 \\
0 \\
\end{array}$} & \multirow{2}{*}{$\begin{array}{l}2 \\
1 \\
\end{array}$} & \multirow{2}{*}{$\begin{array}{l}2 \\
2\end{array}$} & 2 & 2 & & 2 & \\
\hline & & & & & & & & & & & & & & & & & & & & & & 3 & 4 & 5 & 6 & \\
\hline & omp & ore & nde & $\mathrm{er}$ & de & $\mathrm{sp}$ & ala & ras & sã & es & c & as & om & le & & & & & & & & & & & & \\
\hline - & $\mathbf{X}$ & - & - & - & $\mathbf{X}$ & - & - & - & - & - & - & - & - & X & - & - & - & $\mathbf{X}$ & - & $\mathbf{X}$ & X & - & - & - & - & 06 \\
\hline & $\begin{array}{l}\text { ifer } \\
\text { entr }\end{array}$ & & & & & & & & & & & & & & & & & $\mathrm{pc}$ & & & & & & & & \\
\hline $\bar{X}$ & & - & $\mathbf{X}$ & $\mathbf{X}$ & $\mathbf{X}$ & - & - & $\mathbf{X}$ & $\mathbf{X}$ & $\mathbf{X}$ & $\mathbf{X}$ & - & $\mathbf{X}$ & $\mathrm{X}$ & - & - & - & $\mathbf{X}$ & $\mathbf{X}$ & - & $\mathrm{X}$ & $\mathbf{X}$ & - & - & $\mathbf{X}$ & 15 \\
\hline & ecol & nhe & cer & as 1 & etr: & $\mathrm{s}, \mathrm{r}$ & on & ear & do & & & & & & & & & & & & & & & & & \\
\hline $\mathrm{X}$ & & - & - & $\mathbf{X}$ & $\mathbf{X}$ & - & - & $\mathbf{X}$ & $\mathbf{X}$ & $\mathbf{X}$ & - & - & - & $\mathrm{X}$ & $\mathrm{X}$ & - & - & $\mathbf{X}$ & - & - & $\mathrm{X}$ & $\mathrm{X}$ & - & $\mathrm{X}$ & - & 12 \\
\hline & rafa & $\mathrm{ra}$ & let & ras & do & $1 \mathrm{fa}$ & bet & & & & & & & & & & & & & & & & & & & \\
\hline - & & - & - & $\mathbf{X}$ & $\mathbf{X}$ & - & $\mathbf{X}$ & $\mathbf{X}$ & - & - & - & - & - & $\mathrm{X}$ & - & - & - & $\mathbf{X}$ & - & - & - & - & $\mathbf{X}$ & - & - & 07 \\
\hline & onh & ece & $\mathrm{rdi}$ & fere & nte & til & $\mathrm{OS}$ & $\mathrm{de}$ & etr & & & & & & & & & & & & & & & & & \\
\hline X & $\mathbf{X}$ & - & - & $\mathbf{X}$ & $\mathbf{X}$ & $\mathbf{X}$ & $\mathbf{X}$ & $\mathbf{X}$ & $\mathbf{X}$ & - & - & - & - & X & $\bar{X}$ & $\mathrm{X}$ & - & $\mathbf{X}$ & X & - & - & $\mathrm{X}$ & $\mathbf{X}$ & - & $\bar{X}$ & 16 \\
\hline & onh & ece & $\mathrm{rac}$ & orde & $\mathrm{m}$ & lifa & bét & & & & & & & & & & & & & & & & & & & \\
\hline & $\mathbf{X}$ & - & - & $\mathbf{X}$ & - & - & $\mathbf{X}$ & $\mathbf{X}$ & $\mathbf{X}$ & $\mathbf{X}$ & $\mathbf{X}$ & - & $\mathrm{X}$ & $\mathrm{X}$ & X & $\mathrm{X}$ & - & $\mathbf{X}$ & - & - & $\bar{X}$ & - & - & $\mathbf{X}$ & - & 14 \\
\hline & eco & nhe & cer & e n & om & ear & a 1 & etra & 1n & cia & $\mathrm{d}$ & $\mathrm{p}_{1}$ & ópr & io & non & le & / 0 & $\mathrm{~d} \mathrm{de}$ & ol & tra & $p$ & alas & & & & \\
\hline & $\mathbf{X}$ & - & - & - & - & - & - & $\mathbf{X}$ & - & - & - & - & $\mathbf{X}$ & - & $\mathrm{X}$ & - & - & - & - & - & - & - & - & - & - & 04 \\
\hline & iscre & eve & co & $\mathrm{m} \mathrm{l}$ & etra & $\mathrm{de}$ & im & ore & $\mathrm{sa}$ & $\mathrm{ma}$ & üs & ula & & & & & & & & & & & & & & \\
\hline - & $\mathbf{X}$ & - & $\mathbf{X}$ & - & - & - & $\mathbf{X}$ & - & $\mathbf{X}$ & $\mathbf{X}$ & $\mathbf{X}$ & - & $\mathrm{X}$ & - & - & - & - & $\mathbf{X}$ & - & - & - & - & - & - & - & 08 \\
\hline & scre & vel & cor & $\mathrm{n} \mathrm{le}$ & tra & cur & siv & & & & & & & & & & & & & & & & & & & \\
\hline & $\mathbf{X}$ & - & - & - & - & - & $\mathbf{X}$ & - & 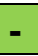 & - & $\mathbf{X}$ & - & - & - & $=$ & - & - & $\mathbf{X}$ & $=$ & - & - & $=$ & - & - & $\mathbf{X}$ & 05 \\
\hline & $\mathrm{omp}$ & ore & nde & 2. & $\mathrm{de}_{1}$ & & vra & $\mathrm{sd}$ & & ntt & & $\mathrm{de}$ & 111 & & pal & III & & $\operatorname{lgu}$ & & le & & & & & & \\
\hline & - & - & - & - & - & - & - & $\mathbf{X}$ & - & $\mathbf{X}$ & - & - & $\mathrm{X}$ & & $\mathbf{X}$ & $\mathrm{X}$ & - & - & - & - & - & - & - & - & - & 05 \\
\hline & & & & & & & & & & & & & & & & & & & & & & & & & & \\
\hline- & - & - & - & - & - & - & - & $\mathbf{X}$ & - & $\mathbf{X}$ & - & - & - & - & - & - & 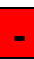 & $\mathbf{X}$ & - & - & - & - & $\mathrm{X}$ & - & - & 04 \\
\hline
\end{tabular}

Olh@res, Guarulhos, v. 1, n. 2, p. 69-99, Novembro, 2013. 
Reflexões sobre o ensino do sistema de escrita alfabética em documentos curriculares: implicações para a formação de professores

Vale ressaltar que a alta frequência de documentos que fizeram referência ao trabalho com letras do alfabeto não caracteriza, necessariamente, a adesão à métodos sintéticos. Nos documentos, não foram observadas orientações de tratamento linear e sequencial das letras e nem o pressuposto típico dos métodos sintéticos de que tal aprendizagem seria pré-requisito para as outras aprendizagens da leitura e escrita. Pelo contrário, as recomendações frequentes eram as de que as crianças devem, desde o início da escolarização, participar de situações de leitura e produção de textos.

\subsection{Habilidades de consciência fonológica e relações entre unidades sonoras e representações gráficas}

O sistema de escrita alfabética tem como propriedade fundamental o princípio grafofônico, ou seja, as unidades gráficas mantêm relação com as unidades sonoras de modo que as letras notam ou substituem a pauta sonora das palavras que pronunciamos (LEAL, MORAIS, 2010). Como decorrência dessa propriedade do sistema de escrita alfabética, as habilidades de reflexão sobre a dimensão sonora das palavras são mobilizadas no processo de aprendizagem da escrita, tal como defendem autores como Bryant e Bradley (1987) e Lundberg, Frost e Peterson (1988).

No entanto, outros estudos mostram que nem todas as habilidades fonológicas têm repercussão no processo de alfabetização. Tais estudos evidenciam que algumas habilidades são importantes, como as de segmentar palavras em sílabas e comparar palavras quanto às semelhanças sonoras e gráficas, mas outras, como as de segmentação fonêmica, são consequência do processo de alfabetização (MORAIS E LIMA, 1989; MORAIS, 2004).

Segundo Morais (2004), a consciência fonológica, que contempla habilidades de segmentar palavras em sílabas e comparar palavras quanto às semelhanças e diferenças sonoras e gráficas, e não a consciência fonêmica, é importante no processo de alfabetização.

Olh@res, Guarulhos, v. 1, n. 2, p. 69-99, Novembro, 2013. 
Além disso, tal autor defende que a consciência fonológica, embora seja importante, não é suficiente para a conquista da base alfabética, pois o aprendiz precisa entender o funcionamento do sistema de escrita para fazer uso das habilidades fonológicas de maneira efetiva no momento da escrita.

Essa é uma diferença fundamental entre o modo como adeptos dos métodos fônicos e de uma abordagem da alfabetização na perspectiva do letramento lidam com as questões relativas às relações entre consciência fonológica e alfabetização.

$\mathrm{Na}$ abordagem da alfabetização na perspectiva do letramento concebese que o aprendiz é ativo no processo de aprendizagem, de modo que elabora hipóteses sobre os princípios do sistema de escrita, e não simplesmente memoriza correspondências grafofônicas, tal como prescreve o método fônico. Assim, na abordagem da alfabetização na perspectiva do letramento concebe-se que o objeto de aprendizagem é um sistema de escrita que requer aprendizagens conceituais, havendo, portanto, ênfase na compreensão, diferentemente do que ocorre na abordagem dos métodos fônicos, em que se enfatiza a memorização e a aquisição de habilidades perceptuais básicas, como as visuais, motoras e auditivas. Por fim, assim como ocorre na comparação com outros métodos sintéticos, é importante ressaltar que a abordagem da alfabetização na perspectiva do letramento não propõe uma sequência linear no ensino de letras / palavras, além de defender a necessidade de que desde o início da escolarização se garanta um contato intenso e ativo com textos de circulação social.

Considerando tais diferenças, não se pode classificar uma determinada opção metodológica como sintética simplesmente porque se defende a proposição de atividades de reflexões fonológica para os aprendizes. De fato, tal como pode ser observado na Tabela 3, abaixo, nos documentos curriculares analisados foram evidenciadas orientações 
Reflexões sobre o ensino do sistema de escrita alfabética em documentos curriculares: implicações para a formação de professores

variadas relativas às reflexões sobre a dimensão sonora das palavras e relações com o registro gráfico, não havendo, porém, características que classifiquem as propostas como representativas de métodos fônicos.

Tabela 3: Frequência e percentual de documentos que contemplam orientações relativas ao desenvolvimento de habilidades fonológicas e relações entre unidades sonoras e representações gráficas

\begin{tabular}{|l|c|c|c|c|}
\hline \multicolumn{1}{|c|}{ Categorias } & $\begin{array}{c}\text { Documentos } \\
\text { Municipais } \\
(\mathbf{1 2})\end{array}$ & $\begin{array}{c}\text { Documentos } \\
\text { Estaduais } \\
(\mathbf{1 4})\end{array}$ & Total & $\begin{array}{c}\text { Percentual } \\
(\mathbf{\%})\end{array}$ \\
\hline $\begin{array}{l}\text { Compreender que a escrita nota } \\
\text { propriedades da pauta sonora }\end{array}$ & $\mathbf{7}$ & $\mathbf{7}$ & $\mathbf{1 4}$ & $\mathbf{5 3 , 8 \%}$ \\
\hline $\begin{array}{l}\text { Compreender que as palavras podem ser } \\
\text { segmentadas em sílabas, saber contá-las } \\
\text { oralmente e comparar as palavras quanto } \\
\text { ao número de sílabas. }\end{array}$ & $\mathbf{4}$ & $\mathbf{3}$ & $\mathbf{7}$ & $\mathbf{2 6 , 9 \%}$ \\
\hline $\begin{array}{l}\text { Comparar palavras oralmente quanto às } \\
\text { semelhanças e diferenças sonoras. }\end{array}$ & $\mathbf{3}$ & $\mathbf{3}$ & $\mathbf{6}$ & $\mathbf{2 3 , 1 \%}$ \\
\hline $\begin{array}{l}\text { Comparar palavras escritas quanto às } \\
\text { semelhanças e diferenças sonoras }\end{array}$ & $\mathbf{3}$ & $\mathbf{5}$ & $\mathbf{8}$ & $\mathbf{3 0 , 8 \%}$ \\
\hline $\begin{array}{l}\text { Compreender que as letras correspondem } \\
\text { aos fonemas (as letras notam unidades } \\
\text { menores que as sílabas) }\end{array}$ & $\mathbf{7}$ & $\mathbf{7}$ & $\mathbf{1 4}$ & $\mathbf{5 3 , 8 \%}$ \\
\hline $\begin{array}{l}\text { Compreender que a ordem com que as } \\
\text { letras são registradas na notação das } \\
\text { palavras corresponde à ordem com que os } \\
\text { fonemas são pronunciados. }\end{array}$ & $\mathbf{1}$ & $\mathbf{1}$ & $\mathbf{2}$ & $\mathbf{7 , 7 \%}$ \\
\hline
\end{tabular}

Como exposto acima, a categoria mais frequente nesse bloco foi a que sintetiza o princípio fundamental da base alfabética: compreender que as letras correspondem aos fonemas (as letras notam unidades menores que as sílabas), presente em pouco mais da metade (14) dos documentos analisados.

No Quadro 3, a seguir, vemos que dos 26 documentos analisados, 21, o equivalente a $80,8 \%$, orientam para a necessidade de realização de atividades de reflexão fonológica, contemplando, no mínimo, uma das categorias que compõem esse bloco. 
Quadro 3: Identificação dos documentos que contemplam orientações relativas ao desenvolvimento de habilidades fonológicas e relações entre unidades sonoras e representações gráficas

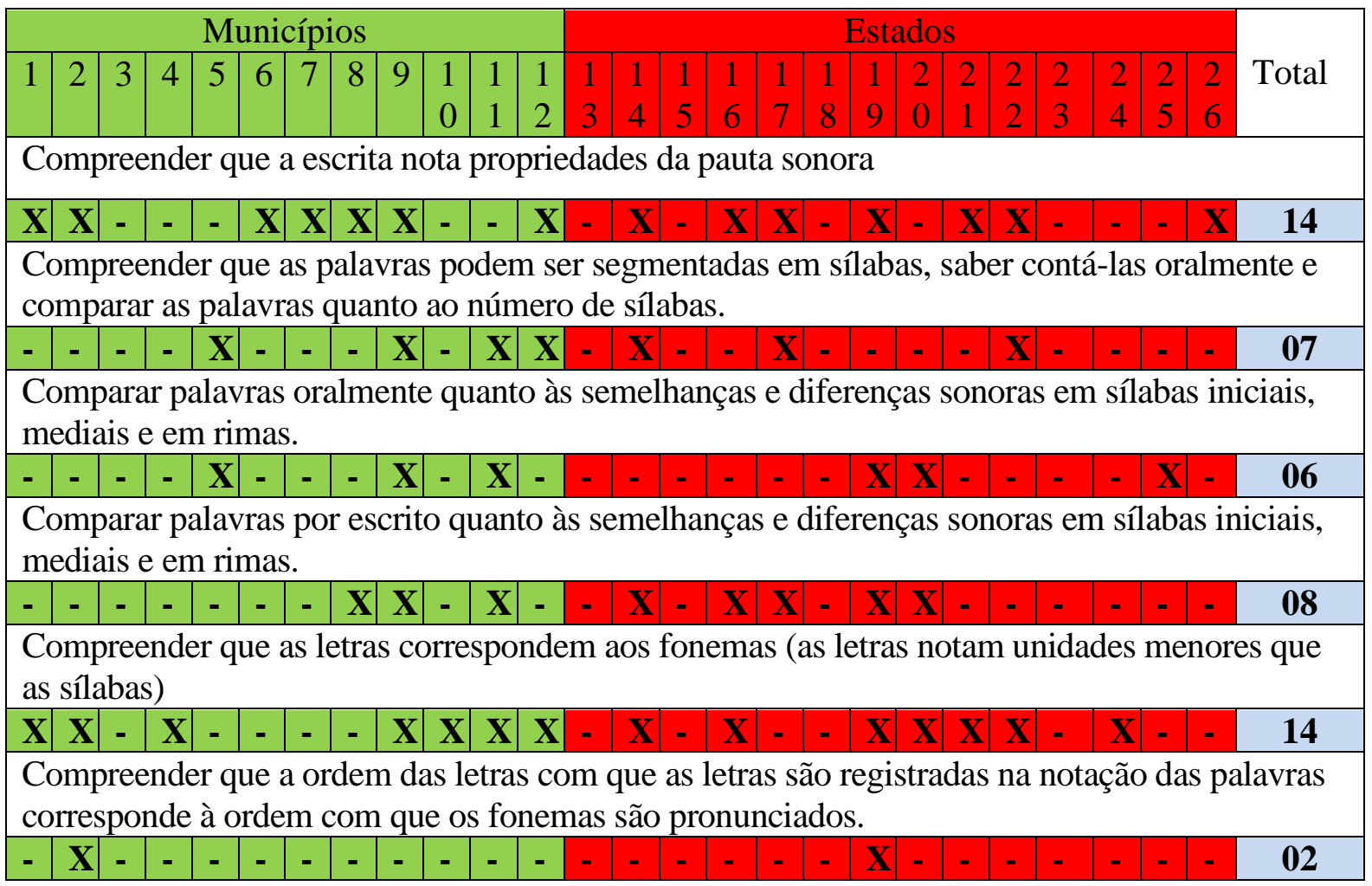

\subsection{Conhecimentos e habilidades relacionados aos diferentes tipos de sílabas}

Os conhecimentos sobre o funcionamento do sistema de escrita alfabética envolvem a compreensão de que as palavras são compostas de sílabas que, embora tenham regularidades, têm grande variação.

Como se pode verificar na Tabela 4 , as categorias incluídas neste bloco de conhecimento foram as menos citadas nos documentos analisados. De acordo com o Quadro 4, dos 26 documentos, 07 $(26,9 \%)$ contemplam, no mínimo, umas das três categorias elencadas a seguir.

Olh@res, Guarulhos, v. 1, n. 2, p. 69-99, Novembro, 2013. 
Reflexões sobre o ensino do sistema de escrita alfabética em documentos curriculares: implicações para a formação de professores

Tabela 4: Frequência e percentual de documentos que contemplam conhecimentos e habilidades relacionados aos diferentes tipos de sílabas

\begin{tabular}{|l|c|c|c|c|}
\hline \multicolumn{1}{|c|}{ Categorias } & $\begin{array}{c}\text { Documentos } \\
\text { Municipais } \\
(\mathbf{1 2})\end{array}$ & $\begin{array}{c}\text { Documentos } \\
\text { Estaduais } \\
(\mathbf{1 4})\end{array}$ & Total & $\begin{array}{c}\text { Percentual } \\
\mathbf{( \% )}\end{array}$ \\
\hline $\begin{array}{l}\text { Compreender que as vogais estão } \\
\text { presentes em todas as sílabas. }\end{array}$ & $\mathbf{0}$ & $\mathbf{0}$ & $\mathbf{0}$ & $\mathbf{0 \%}$ \\
\hline $\begin{array}{l}\text { Compreender que existe variação na } \\
\text { estrutura das sílabas. }\end{array}$ & $\mathbf{4}$ & $\mathbf{2}$ & $\mathbf{6}$ & $\mathbf{2 3 , 1 \%}$ \\
\hline $\begin{array}{l}\text { Ler e escrever palavras com diferentes } \\
\text { estruturas silábicas. }\end{array}$ & $\mathbf{2}$ & $\mathbf{1}$ & 3 & $\mathbf{1 1 , 5 \%}$ \\
\hline
\end{tabular}

Quadro 4: Identificação dos documentos que contemplam conhecimentos e habilidades relacionados aos diferentes tipos de sílabas

\begin{tabular}{|c|c|c|c|c|c|c|c|c|c|c|c|c|c|c|c|c|c|c|c|c|c|c|c|c|c|c|}
\hline \multicolumn{12}{|c|}{ Municípios } & \multicolumn{14}{|c|}{ Estados } & \multirow[b]{3}{*}{ Total } \\
\hline \multirow{2}{*}{\multicolumn{2}{|c|}{\begin{tabular}{l|l}
1 & 2 \\
\end{tabular}}} & 3 & 4 & 5 & 6 & 7 & 8 & 9 & 1 & 1 & 1 & 1 & 1 & 1 & 1 & 1 & 1 & 1 & 2 & 2 & 2 & 2 & 2 & 2 & 2 & \\
\hline & & & & & & & & & 0 & & 2 & & 4 & 5 & 6 & 1 & 8 & 9 & 0 & 1 & 2 & $J$ & 4 & 5 & 6 & \\
\hline \multicolumn{27}{|c|}{ Compreender que as vogais estão presentes em todas as sílabas. } \\
\hline - & - & - & - & - & - & - & - & - & - & - & - & - & - & - & - & - & - & - & - & - & - & - & - & - & - & 00 \\
\hline \multicolumn{27}{|c|}{ Compreender que existe variação na estrutura das sílabas. } \\
\hline- & - & - & $\mathbf{X}$ & & $\mathbf{X}$ & - & - & - & $\mathbf{X}$ & $\mathbf{X}$ & - & & - & - & - & - & - & $\mathbf{X}$ & & $=$ & - & - & - & - & - & 06 \\
\hline \multirow{2}{*}{\multicolumn{27}{|c|}{ Ler e escrever palavras com diferentes estruturas silábicas. }} \\
\hline & $\mathbf{X}$ & - & & & & - & & & & - & - & & - & & - & - & & $\mathbf{X}$ & & - & - & - & - & - & - & 03 \\
\hline
\end{tabular}

Uma hipótese plausível para a pequena presença de orientações acerca do trabalho com as sílabas é que as propostas curriculares tenham preferido evitar a interpretação de que estariam, com isso, adotando uma perspectiva silábica, própria de alguns métodos sintéticos. Porém, na abordagem da alfabetização na perspectiva do letramento, os conhecimentos sobre as sílabas também são considerados relevantes para o processo de alfabetização. A esse respeito, por exemplo, Albuquerque (2005) ressalta a importância do trabalho com sílabas, por meio de atividades diversificadas e sistemáticas com a mediação docente, diferentemente do que acontece na concepção tradicional, em que o ensino da base alfabética é feito por meio do treino de padrões silábicos. Sobre isso a autora afirma que

Olh@res, Guarulhos, v. 1, n. 2, p. 69-99, Novembro, 2013. 
"é possível, sim, alfabetizar sem o tradicional bá, bé, bi, bó, bu, a partir do desenvolvimento de atividades que não só envolvam a leitura e produção de diferentes gêneros, mas que também levem os alunos a refletir sobre as características do nosso sistema de escrita" (ALBUQUERQUE, 2005, p. 106).

\section{Considerações finais: o ensino da base alfabética e o processo de formação de professores no pacto nacional pela alfabetização na idade certa}

Como foi dito anteriormente, quatro dimensões principais do ensino da leitura e da escrita podem ser considerados nas discussões sobre alfabetização: (1) Apropriação do Sistema de Escrita Alfabética; (2) Desenvolvimento de habilidades/capacidades de produção e compreensão de textos orais e escritos: (3) Inserção em práticas sociais diversas, com base no trabalho de produção, compreensão e reflexão sobre gêneros textuais variados; (4) Reflexão sobre temáticas relevantes por meio dos textos.

Os dados expostos neste artigo focaram na primeira dimensão, o ensino do sistema de escrita alfabética, mas é importante informar que as quatro dimensões foram contempladas nos documentos (Leal e Brandão, 2012), com diferenças quanto à ênfase dada a cada uma delas $^{2}$.

Tal como exposto em outro artigo (LEAL, BRANDÃO, ALMEIDA E VIEIRA, 2013), nos documentos analisados a dimensão do ensino do SEA é contemplada, mas há diferenças quanto às concepções acerca de como tal aprendizagem ocorre.

\footnotetext{
${ }^{2}$ Em outros artigos, reflexões sobre tais dimensões foram abordados, com base nos dados dessa pesquisa.
}

Olh@res, Guarulhos, v. 1, n. 2, p. 69-99, Novembro, 2013. 
Reflexões sobre o ensino do sistema de escrita alfabética em documentos curriculares: implicações para a formação de professores

A tendência mais recorrente é a de que o SEA precisa ser tratado em suas especificidades, tal como proposto por Soares (2003), mas de modo integrado e simultâneo ao trabalho de inserção dos estudantes em situações de leitura e produção de textos $(65,4 \%)$. Nesses casos, no mínimo, três, dos quatro blocos de conhecimentos analisados anteriormente, foram de algum modo contemplados.

A segunda tendência encontrada $(30,8 \%)$ foi a que agrupou os documentos que enfatizavam o trabalho com textos variados, em situações significativas de leitura e produção, com pouca ênfase no ensino da base alfabética, tal como exemplificado no início deste artigo, com trechos do documento de Mato Grosso.

Apenas um documento $(3,8 \%)$ aproximou-se de perspectivas mais sintéticas de alfabetização.

\begin{tabular}{|l|l|l|l|l|}
\hline Categorias & $\begin{array}{l}\text { Documentos } \\
\text { Municipais }\end{array}$ & $\begin{array}{l}\text { Documentos } \\
\text { Estaduais }\end{array}$ & Total & $\begin{array}{l}\text { Percentual } \\
(\%)\end{array}$ \\
\hline Tendência 1 & 03 & 05 & 08 & $30,8 \%$ \\
\hline Tendência 2 & 00 & 01 & 01 & $03,8 \%$ \\
\hline Tendência 3 & 09 & 08 & 17 & $65,4 \%$ \\
\hline Total & 12 & 14 & 26 & $100 \%$ \\
\hline
\end{tabular}

Em consonância com os pressupostos que caracterizam a terceira tendência foi concebido o projeto de formação de professores no âmbito do Pacto Nacional pela Alfabetização na Idade Certa ${ }^{3}$. No documento de Apresentação do Programa é afirmado que,

\footnotetext{
3 A proposta de formação e os materiais didáticos construídos para subsidiar tal formação foram elaborados por pesquisadores de doze universidades e instituições de pesquisa: Universidade Federal de Pernambuco (UFPE), Fundação Joaquim Nabuco (FUNDAJ), Instituto Federal de Educação Ciência e Tecnologia de Pernambuco (IFPE), Universidade do Estado da Bahia (UNEB), Universidade Estadual de Campinas (UNICAMP), Universidade Estadual de Ponta Grossa (UEPG), Universidade Estadual Paulista Júlio de Mesquita Filho (UNESP), Universidade Federal de Juiz de Fora (UFJF), Universidade Federal do Amapá (UNIFAP), Universidade Federal do Rio de Janeiro (UFRJ), Universidade Federal Rural do SemiÁrido (UFERSA), Universidade Federal Rural de Pernambuco (UFRPE).
}

Olh@res, Guarulhos, v. 1, n. 2, p. 69-99, Novembro, 2013. 
desde os primeiros anos de escolarização, espera-se que os docentes planejem situações de escrita que, ao mesmo tempo favoreçam a aprendizagem do funcionamento da escrita alfabética e possibilitem o acesso aos textos escritos de modo a garantir a inserção social em diversos ambientes e tipos de interação (BRASIL, 2012, p. 22).

Tal citação evidencia a afiliação da proposta à terceira tendência exposta anteriormente. A proposta sustenta-se ainda em quatro princípios centrais que são considerados ao longo do desenvolvimento do trabalho pedagógico:

1. O Sistema de Escrita Alfabética é complexo e exige um ensino sistemático e problematizador;

2. O desenvolvimento das capacidades de leitura e de produção de textos ocorre durante todo o processo de escolarização, mas deve ser iniciado logo no começo da Educação Básica, garantindo acesso precoce a gêneros discursivos de circulação social e a situações de interação em que as crianças se reconheçam como protagonistas de suas próprias histórias;

3. Conhecimentos oriundos das diferentes áreas de conhecimento podem e devem ser apropriados pelas crianças, de modo que elas possam, ouvir, falar, ler, escrever sobre temas diversos e agir na sociedade;

4. A ludicidade e o cuidado com as crianças são condições básicas nos processos de ensino e de aprendizagem. (BRASIL, 2012, p. 27)

Há, portanto, atenção às dimensões da alfabetização discutidas neste artigo, que se concretizam nos doze objetivos gerais que guiam todos os documentos. O primeiro objetivo já explicita tal afiliação:

1. Entender a concepção de alfabetização na perspectiva do letramento, com aprofundamento de estudos utilizando, sobretudo, as obras pedagógicas do PNBE do Professor e outros textos publicados pelo MEC (BRASIL, 2012, p. 31).

No objetivo 2, há uma defesa de que é preciso garantir direitos, tal como discutimos no início deste artigo. Nos cadernos de formação há uma síntese de diferentes conhecimentos e habilidades relativos ao processo de alfabetização, construídos, sobretudo, com base no que foi encontrado nos documentos curriculares de capitais e redes estaduais

Olh@res, Guarulhos, v. 1, n. 2, p. 69-99, Novembro, 2013. 
Reflexões sobre o ensino do sistema de escrita alfabética em documentos curriculares: implicações para a formação de professores

brasileiros. Nesses materiais, são detalhados aspectos tanto dos eixos de leitura e produção de textos, quanto do ensino da base alfabética.

2. Aprofundar a compreensão sobre o currículo nos anos iniciais do Ensino Fundamental e sobre os direitos de aprendizagem e desenvolvimento nas diferentes áreas de conhecimento. (BRASIL, 2012, p. 31)

A preocupação com as especificidades do ensino do SEA também pode ser claramente identificada nos objetivos 9 e 11, que focam aspectos relativos aos debates sobre os métodos de alfabetização e onde se assume uma perspectiva que, de fato, compreende a necessidade de sistematicidade no ensino do sistema de escrita alfabético.

9. Entender as relações entre consciência fonológica e alfabetização, analisando e planejando atividades de reflexão fonológica e gráfica de palavras, utilizando materiais distribuídos pelo MEC;

11. Conhecer a importância do uso de jogos e brincadeiras no processo de apropriação do Sistema de Escrita Alfabética, analisando jogos e planejando aulas em que os jogos sejam incluídos como recursos didáticos (BRASIL, 2012, p. 31).

Os jogos que são descritos e usados como exemplos são destinados ao trabalho de ensino da leitura e da escrita, de modo reflexivo, objetivando a apropriação pela criança dos conhecimentos necessários à compreensão do funcionamento do sistema de escrita.

Apesar de haver, em várias unidades que compõem os materiais utilizados nos encontros de formação, reflexões sobre o ensino do SEA, atendendo aos objetivos aqui citados, não se pode caracterizar tal proposta como oriunda de perspectivas sintéticas ou analíticas. 
Assim como os documentos curriculares analisados, os pressupostos acerca da aprendizagem do SEA fundam-se em princípios comuns em abordagens sociointeracionistas, como os da problematização, reflexão, interação no processo de aprendizagem.

Há, ainda, a defesa da necessidade de articular diferentes componentes curriculares e diferentes dimensões da alfabetização, como pode ser observado nos objetivos 6,10 e 12 .

6. Planejar o ensino na alfabetização, analisando e criando propostas de organização de rotinas da alfabetização na perspectiva do letramento;

10. Compreender a importância da literatura nos anos iniciais do Ensino Fundamental e planejar situações de uso de obras literárias em sala de aula;

12. Analisar e planejar projetos didáticos e sequências didáticas para turmas de alfabetização, assim como prever atividades permanentes, integrando diferentes componentes curriculares e atividades voltadas para o desenvolvimento da oralidade, leitura e escrita. (BRASIL, 2012, p. 31)

Esses objetivos concretizam-se em todas as unidades do curso, que inserem reflexões teóricas, relatos de pesquisa e relatos de experiências docentes que buscam assegurar uma alfabetização em sentido ampliado, tal como pode ser reconhecido nos demais objetivos citados no caderno de apresentação do Programa:

3. Compreender a importância da avaliação no ciclo de alfabetização, analisando e construindo instrumentos de avaliação e de registro de aprendizagem;

4. Compreender e desenvolver estratégias de inclusão de crianças com deficiência visual, auditiva, motora e intelectual, bem como crianças com distúrbios de aprendizagem no cotidiano da sala de aula;

5. Conhecer os recursos didáticos distribuídos pelo Ministério da Educação (livros didáticos e obras complementares aprovados no PNLD; livros do PNBE e PNBE Especial; jogos didáticos distribuídos pelo MEC) e planejar situações didáticas em que tais materiais sejam usados;

7. Compreender a importância de organizar diferentes agrupamentos em sala de aula, 
Reflexões sobre o ensino do sistema de escrita alfabética em documentos curriculares: implicações para a formação de professores

adequando os modos de organização da turma aos objetivos pretendidos;

8. Criar um ambiente alfabetizador, que favoreça a aprendizagem das crianças (BRASIL, 2012, p. 31).

Enfim, as análises dos documentos curriculares evidenciaram que há diferentes tendências quanto ao que concebemos como alfabetização ou como devemos alfabetizar, mas muitas convergências foram encontradas, como a de que é necessário inserir os estudantes precocemente em situações miméticas às praticadas fora da escola. Tal pressuposto fundamental precisa ser considerado nas propostas de formação ofertadas aos professores de escolas públicas. O Pacto Nacional pela Alfabetização na Idade Certa é um desses programas em que tais aproximações podem ser identificadas.

Por outro lado, os documentos se diferenciam, sobretudo, quanto às recomendações acerca da necessidade, ou não, de tratar o ensino do SEA de modo sistemático. No programa de formação do Pacto Nacional pela Alfabetização na Idade Certa há uma defesa de que é necessário abordar as especificidades desse ensino, sem incorrer no retorno aos métodos tradicionais de alfabetização. 


\section{Referências bibliográficas}

ALBUQUERQUE, E. B. C. e LEITE, T. M. R. Explorando as letras na Educação Infantil. In: BRANDÃO, Ana Carolina Perrusi; ROSA, Ester Calland de Sousa (org.). Ler e Escrever na Educação Infantil: discutindo práticas pedagógicas. Belo Horizonte: Autêntica Editora, 2010.

ALBUQUERQUE, Eliana Borges C. Alfabetizar sem "bá-bé-bi-bó-bu": uma prática possível? In: LEAL. Telma Ferraz; ALBUQUERQUE, Eliana Borges Correia de (org.). Desafios da educação de jovens e adultos: construindo práticas de alfabetização. Belo Horizonte: Autêntica, 2005.

ARAÚJO, M. T. Alfabetização tem conteúdos? In: GARCIA, Regina Leite (org.) A formação da professora-alfabetizadora: reflexões sobre a prática. $2^{\mathrm{a}}$ Ed. São Paulo: Cortez, 1998.

BARDIN, L. Análise de Conteúdo. Lisboa: Edições 70, LDA. 2007.

BRASIL. Pacto Nacional pela Alfabetização na Idade Certa. Secretaria de Educação Básica- SEB (Caderno de Apresentação). Brasília, 2012.

BRASIL, Parâmetros Curriculares Nacionais. Língua Portuguesa. Secretaria de Estado de Educação. 2001.

BRYANT, P.; BRADLEY, L. Problemas de Leitura na Criança. Porto Alegre: Artes Médicas, 1987.

DECROLY, O.; DEGAND, J. Quelques considérations sur la psychologie etla pédagogie de la lecture. Revue Scientifique, 10, 290-299, 1906.

DOTTRENS, R.; MARGAIRAZ, E. L'appressintage de la lecture par la méthode globale. Neuchâtel, 1951.

FERREIRO, E. Reflexões sobre alfabetização. São Paulo: Cortez; Autores Associados, 1988.

FERREIRO, E.; TEBEROSKY, A. Psicogênese da língua escrita. Porto Alegre: Artes Médicas, 1979 b.

GOODMAN, K. Reading: A psycholinguistic guessing game. Journal of the Reading Specialist. May, 126-137, 1967.

KRATZMEIER, H. Reading in pre-school age. AVTO - Periodico di Vita Scolastica e Amministrativa, 15 (9), 35-46, 1971.

LEAL, T. F, BRANDÃO, A. C. P, ALMEIDA, F. B. S e VIEIRA, E.S. Currículo e alfabetização: implicações para a formação de professores, I Congresso Brasileiro de Alfabetização. 2013.

LEAL, Telma F. e MORAIS. Artur G. O aprendizado do sistema de escrita alfabética: uma tarefa complexa, cujo funcionamento precisamos compreender. In: LEAL, T. F.; ALBQUERQUE, E. B. C.; MORAIS, A. G. (org.). Alfabetizar letrando na EJA: fundamentos teóricos e propostas didáticas. Belo Horizonte: Autêntica Editora, 2010.

Olh@res, Guarulhos, v. 1, n. 2, p. 69-99, Novembro, 2013. 
LEAL, T. F.; BRANDÃO, A. C. P. A. Alfabetização e ensino da Língua Portuguesa: investigando o currículo no Brasil. Relatório de Pesquisa: CNPq, 2012.

LEAL, T.. F.; MORAIS, A. G. A argumentação em textos escritos: a criança e a escola. Belo Horizonte: Autêntica, 2006.

LEITE, T. M.B.R. Alfabetização - Consciência Fonológica, Psicogênese da Escrita e Conhecimento dos Nomes das Letras: um ponto de interseção. Dissertação de Mestrado. Pós-Graduação em Educação da UFPE. Recife: UFPE, 2006.

LUNDBERG, I., FROST, J.; PETERSEN, O. Effects of an extensive program for stimulating phonological awareness in preschool children. Reading Research Quarterly, 23, 1988, p. 263-284.

MATTHEWS, M.M. Teaching to read historically considered. Chicago: The University of Chicago Press, 1966.

MIALARET, G. L'apprendimento della lettura. Roma: Armando, 1967.

MORAIS, Artur G.; LIMA, N.C. Análise Fonológica e Compreensão da Escrita Alfabética: um estudo com crianças da escola pública. Anais do Simpósio LatinoAmericano de Psicologia do Desenvolvimento. Recife, 51-54, 1989.

MORAIS, A. G. A Apropriação do Sistema de Notação Alfabética e o Desenvolvimento de Habilidades de Reflexão Fonológica. Porto Alegre: Letras de Hoje, 2004.

MORAIS, A.G; ALBUQUERQUE, E.B. C; LEAL, T.F. Alfabetização: apropriação do sistema de escrita alfabética. Belo Horizonte, Autêntica, 2005.

MOREIRA, A. F. B.; CANDAU, V. M. Currículo, conhecimento e cultura. In: BEAUCHAMP, J.; PAGEL, S. D.; NASCIMENTO, A. R. Indagações sobre currículo: currículo, conhecimento e cultura. Brasília: Ministério da Educação, Secretaria de Educação Básica. 2007. Disponível em: http://portal.mec.gov.br/seb/arquivos/pdf/Ensfund/indag3.pdf. Acesso em: 01 jul. 2013.

SANTOS, L.P.; PARAÍSO, M.A. O Currículo como Campo de Luta. In: Presença Pedagógica, n. 7, 1996.

SKINNER, B.F.; CORREL, W. (1974). Pensare e apprendere. Roma: Armando, 1974.

SMITH, F. Decoding: The great fallacy. In Smith, F. Psycholinguistic and reading. New York: Holt, Rinehart and Winston, 1973.

SMITH, F. Understanding reading. New York: Holt, Rinehart and Winston, 1971.

SOARES, M. B. Letramento: um tema em três gêneros. $2^{\mathrm{a}}$ ed. Belo Horizonte, Autêntica, 2003.

SULLIVAN, J. Language experience in the content áreas. The Reading Teacher, 39 (7), 665-667, 1986. 
Violaîne Bigot ${ }^{1}$

Universidade Sorbonne Nouvelle

\section{Resumo}

Este relato etnográfico descreve a participação de S., criança de sete anos de idade e falante não-nativa de língua francesa, nas interações cotidianas em sala de aula. Os dados foram coletados ao longo de cinco meses em classe regular, à qual $\mathrm{S}$. foi integrado, bem como no curso de francês língua estrangeira, por ele frequentado, algumas horas por semana, com outros alunos não-nativos. $\mathrm{O}$ estudo busca mostrar como o desenvolvimento de sua competência comunicativa (ou, mais amplamente, sua socialização em L2) compete com e/ou ajuda, e/ou é ajudado pelo desenvolvimento de outros aprendizagens e por sua socialização escolar.

Palavras-chave: Socialização em L2; Socialização escolar; Aprendizagens escolares; Competência comunicativa em L2; $\quad$ Aquisição em L2.

1 Docente da Universidade Sorbonne Nouvelle - Paris 3. Email: violaine.bigot@univparis3.fr. Texto traduzido por Márcia Romero e Thatiana Ribeiro Vilela. Artigo originalmente publicado sob o título "L'enfant nonfrancophone scolarisé dans une classe ordinaire : convergence ou concurrence de la socialisation langagière et de la socialisation scolaire ?", in. CANDELIER et al. (eds.): Conscience $d u$ plurilinguisme. Presses Universitaires de Rennes, 2008. Sob o aval da autora, o título do artigo em português foi readequado por sugestão dos tradutores.

Olh@res, Guarulhos, v. 1, n. 2, p. 100-119, Novembro, 2013. 


\title{
PUPILS WITH LITTLE MASTERY OF THE LANGUAGE OF SCHOOLING: CONVERGENCE OR CONFLICT BETWEEN LANGUAGE SOCIALIZATION AND SCHOOL SOCIALIZATION
}

\begin{abstract}
This ethnographic report describes the participation of $\mathrm{S}$, a seven year old non-native speaker child, in the daily classroom interactions of his class. Data were collected over five months. in the "ordinary" classroom where he was integrated as well as in the "special needs" course he attends a few hours a week with other non-native pupils. The study aims at showing how the development of his communicative competence (or more widely, his "L2 socialization) compete with and/or help, and/or is helped by the development of other learnings and of his scholar socialization.
\end{abstract}

Keywords: L2 socialization; Scholar socialization; Scholar learnings; L2 communicative competence; L2 acquisition. 


\section{Contexto de estudo e questões iniciais}

Muitas pesquisas de tipo etnográfico, fundamentadas, como a nossa, em análises de interações verbais em sala de aula, permitiram, nos últimos anos, avançar na compreensão do desenvolvimento das trocas verbais das quais participam as crianças e os adolescentes "alófonos",2 nos primeiros meses de sua escolarização (ver, particularmente, GAJO e MONDADA 2000, VASSEUR 2003, RIVIERE 2005). Nosso estudo inscreve-se nesta perspectiva, mas se interessa por um modo de integração diferente que tende a se desenvolver e que consiste em escolarizar as crianças, desde a sua chegada na França, em classes "regulares". Essa forma de escolarização pouco foi estudada por pesquisas etnográficas no contexto francês ${ }^{3}$.

Assim, na academia de Nantes $^{4}$, a maioria das crianças e dos adolescentes, se tiveram uma escolarização normal antes de sua chegada na França, é direcionada para as classes regulares. Eles só têm um apoio linguístico verdadeiramente específico algumas horas por semana, em que trabalham com uma professora especializada. Com este acolhimento, a integração escolar da criança parece privilegiada: o que lhe é solicitado é, antes, que aprenda o seu "papel de estudante" no sistema educativo francês, que construa as mesmas aprendizagens que as crianças francesas, postulando-se que "a intendência linguística" ${ }^{, 5}$ acontecerá normalmente. O estudo de caso

\footnotetext{
${ }^{2}$ Nota dos Trad. Pessoa cuja língua materna é diferente daquela da comunidade em que vive.

3 Alguns estudos foram realizados fora do contexto francês. Podemos citar particularmente o estudo de WELLET (1995), que trata de uma sala mista (5 alunos alófonos em uma sala com 22 alunos) em uma escola internacional de um campus universitário norte-americano e o estudo de PALLOTTI (2005) sobre a socialização linguageira de uma aluna marroquina em uma escola italiana de educação infantil.

4 Nota dos Trad. Na França, a academia constitui uma divisão territorial e administrativa da Universidade, que agrega um conjunto de estabelecimentos e de professores de ensino público de todos os níveis. Nantes, por sua vez, é uma cidade francesa.

${ }^{5}$ Nota dos Trad. Expressão que parece se apoiar na fala do general De Gaulle, que teria afirmado, por volta de 1958, L'intendance suivra toujours, querendo dizer que os problemas econômicos e financeiros do Estado terminam sempre por serem resolvidos, por bem ou por mal. No presente contexto, o que se postula é que se espera que os problemas linguísticos sejam resolvidos normalmente.
}

Olh@res, Guarulhos, v. 1, n. 2, p. 100-119, Novembro, 2013. 
O aluno com pouco domínio na língua da escolarização: convergência ou concorrência da socialização linguageira e da socialização escolar?

apresentado a seguir se propõe a examinar este desafio educativo em uma perspectiva sócio-interacionista centrada nos processos de apropriação da linguagem.

No âmbito das diferentes observações, conduzidas em campo na cidade de Angers, em classes de integração e de acolhimento $^{6}$, acompanhei durante cinco meses um garoto albanês, doravante S., chegado na França em outubro de $2005^{7}$. Com idade de seis anos, foi escolarizado desde a sua chegada em uma sala de ciclo 2 de uma área de educação prioritária chamada de "ambição-êxito". Eu o encontrei, observei e gravei, antes, nos cursos de francês língua estrangeira que ele tinha três vezes por semana com outra aluna, Nora. Depois, entre março e junho de 2006, passei por volta de trinta horas em sua sala (três observações por mês em média) e recolhi por volta de quinze horas de gravações ${ }^{8}$.

Vamos examinar, por meio da análise das trocas verbais das quais $\mathrm{S}$. participa, a maneira como ele se categoriza ou não como bilingue, alófono, aprendiz. Veremos também, por meio desse estudo de caso, que, entre as interações de grandes desafios comunicacionais e certas interações perfeitamente rotinizadas (rituais de datas, etc.), existe toda uma gama de interações que lhe oferecem a ocasião de explorar, às vezes de maneira muito sistemática, diferentes dimensões

\footnotetext{
${ }^{6}$ Nota dos Trad. Uma classe de acolhimento, no original Classe d'accueil (CLA), é um curso de francês como segunda língua oferecido em uma escola da Educação Nacional. Os alunos são conduzidos a esta classe pelo Centro acadêmico para a escolarização das crianças alófonas recém-chegadas (CASNAV) de sua academia.

${ }^{7}$ S. chegou com seus pais e sua irmã menor. Seus pais são não-francófonos no momento de sua chegada na França. Sua mãe fala apenas albanês. Seu pai, pedreiro, especializado na restauração de edifícios, fala também macedônio, língua de sua cidade. A família mora em um centro de solicitantes de asilo situado próximo da escola. S. segue seus estudos com assiduidade. Ele participa com seus pais das atividades extracurriculares oferecidas às famílias pela escola depois do horário de aula.

${ }^{8}$ De acordo com a professora, reservei momentos de observação participante, em que trabalhava com o grupo de alunos do curso preparatório do qual fazia parte S. enquanto a professora trabalhava com os alunos do curso elementar, primeiro ano. Eu era muito solicitada pelos alunos, que quase não me deixavam disponível para "observar". Esses momentos tinham, entre outros objetivos, o de permitir a médio prazo que minha presença fosse aceita pelas crianças para que eu pertubassse o menos possível a sala durante o tempo de observação não-participante. Que todos os adultos e crianças que aceitaram e facilitaram a minha presença na sala sejam aqui agradecidos. Agradeço também a Jo Arditty, que, mais uma vez, me incentivou e apoiou com sua leitura de uma primeira versão deste artigo.
}

Olh@res, Guarulhos, v. 1, n. 2, p. 100-119, Novembro, 2013. 
de sua competência linguística, diferentes micro-sistemas de sua interlíngua.

\section{Uma identidade plurilíngue mantida à distância}

\subsection{Centração do professor nas tarefas de aprendizagem}

Nas sequências de aprendizagem dessa classe regular, as focalizações metalinguísticas são pouco numerosas e mesmo quando, de nosso ponto de vista de observadora e familiarizada com aulas de língua, nos parecia evidente que a incapacidade de $\mathrm{S}$. em realizar uma atividade estava ligada a um problema de compreensão do que lhe era solicitado, as trocas verbais não apresentavam as características de bifocalização descritas por BANGE (1992).

Para ilustrar nosso propósito com um exemplo que é deveras numeroso no corpus, podemos evocar a seguinte interação. A professora (doravante P.) pediu aos alunos que escrevessem palavras começando com a sílaba "sa" e S. propôs "maison” [casa]. Quando, logo depois, P. solicita uma palavra iniciada por "re", S. propôs "savon" [sabão], que é o exemplo que foi considerado e escrito no quadro para a sílaba "sa". Então P. The pergunta "Em SAvon, eu ouço"re"?". Uma aluna propõe "robe" [vestido]. A reposta é comentada e novamente a professora questiona S. ("Então, S. encontrou?"). Este, mais uma vez, propõe "savon" [sabão] e a professora lhe pergunta de novo: "Então, S., eu ouço "re" em “savon"?". Ora, a professora concordou, quando falamos do ocorrido, em admitir que $\mathrm{S}$., que fazia parte dos alunos de $\mathrm{CP}^{9}$ que tinham compreendido globalmente a atividade, tinha provavelmente encontrado um problema de compreensão do que lhe foi solicitado. Na sala, no entanto, ela reagia como faria com qualquer aluno francófono,

\footnotetext{
${ }^{9}$ Nota dos Trad. CP de curso preparatório, primeiro ano de ensino da escola básica francesa. Olh@res, Guarulhos, v. 1, n. 2, p. 100-119, Novembro, 2013.
} 
tentando fazer com que S comparasse a tarefa realizada com a que foi prescrita, sem chamar a atenção para o discurso de prescrição.

Os exemplos de mal-entendidos desse tipo, que não dão lugar às sequências metalinguísticas, são numerosos e, desse ponto de vista, a interação didática à qual é exposto $\mathrm{S}$. diverge da que podemos observar em classes "restritas" de tipo CLIN ou CLA ${ }^{10}$ (cf. particularmente os trabalhos de RIVIERE sobre as instruções verbais dadas em classe de acolhimento). Poderíamos ver, nessas trocas verbais, o fato de se ter perdido a ocasião de se trabalhar, em contexto, verbos frequentes como "commencer par" [começar por] ou "entendre" [ouvir], mas este não é o nosso objetivo. Com efeito, é necessário constatar:

1. que S., apesar dos frequentes mal-entendidos que barram a compreensão do que lhe é solicitado, constrói, no mesmo ritmo que seus colegas de sala, aprendizagens matemáticas e de leitura-escrita. Como veremos abaixo, perguntamo-nos sobre a existência de outros lugares interacionais, na vida da classe, favoráveis a um trabalho metalinguístico;

2. a atitude da professora aparece no momento em que S., de um lado, recusa ser categorizado nas trocas verbais como locutor nãoexperiente ou simplesmente plurilíngue e, de outro, mobiliza seus recursos linguísticos para poder participar, como os outros alunos, das trocas que fundam a vida do grupo na sala, como veremos adiante.

\subsection{Recusa de $S$ de ser categorizado como locutor não-experiente}

Se a professora, nas atividades de aprendizagem, não tematiza os problemas linguísticos que S. pode encontrar, ela o faz, entretanto, seja nas atividades nas quais o vocabulário está no coração da aprendizagem (ficha de palavras cruzadas temáticas ou descoberta de um novo texto no livro de leitura, por exemplo), seja, quase

\footnotetext{
${ }^{10}$ Nota dos Trad. CLIN são classes de iniciação para alunos não-francófonos que acabaram de chegar na França, assim como as CLA, classes de acolhimento já explicadas acima.

Olh@res, Guarulhos, v. 1, n. 2, p. 100-119, Novembro, 2013.
} 
sistematicamente, na atividade ritual de leitura, pela manhã, do cardápio. Encontramos, então, uma ou mais questões direcionadas a S. sobre sua compreensão do vocabulário. Este nunca se engaja naturalmente nessas trocas verbais que o categorizam como locutor pouco experiente. Ele procura evitar ou encurtar as sequências de explicação de vocabulário que lhe são direcionadas. Frequentemente, responde que compreendeu desde a primeira pergunta da professora. Às vezes, quando a pergunta é muito insistente ou precisa, ele admite que não compreendeu, mas, qualquer que seja a explicação que lhe é dada, ele pretende ter compreendido ${ }^{11}$. Pode-se evocar, assim, essa interação surpreendente em que a professora, depois de ter explicado o que é o trigo, pergunta para $\mathrm{S}$ se ele entendeu. S. concorda e quando a professora, para verificar, the pergunta de que cor é o trigo, ele responde rapidamente "rouge" [vermelho]. Esta atitude, que a própria professora comentou durante nossas conversas, pode ser colocada em paralelo com a recusa de $\mathrm{S}$. de ser categorizado como locutor plurilíngue.

\subsection{Recusa de $S$ de ser categorizado como locutor bilíngue}

Por duas vezes, durante minhas observações, S. mostrou bem pouca boa vontade quando suas competências como plurilíngue foram solicitadas. A professora, ao retomar o canto do galo nas diferentes línguas européias, perguntou para S. como era na Albânia. S não manifestou nenhum entusiasmo em responder a pergunta, que pareceu não compreender (o que era surpreendente, dado o contexto). Com a insistência da professora, acabou dizendo, sem nenhum entusiasmo, o termo albanês que designa o galo. Do mesmo modo, na ocasião de um aniversário, "Happy birthday to you" foi cantado pelos alunos em três

\footnotetext{
${ }^{11}$ Notamos, no entanto, que ele sabe muito bem tirar proveito de seu estatuto de alófono nas interações de jogos evidenciadas na parte 3, em que trapaceia "tranquilamente", contando com a clemência de seus colegas, ou, simplesmente, "não escutando" as observações que alguns alunos, um pouco menos "tolerantes", lhe fazem sobre as regras a serem seguidas. Temos um exemplo de estratégia de malentendido cuidadosamente preservado no final da segunda passagem, em que S literalmente não escuta a pergunta de Amal.

Olh@res, Guarulhos, v. 1, n. 2, p. 100-119, Novembro, 2013.
} 
línguas diferentes. Uma aluna de origem turca cantou em sua língua materna. S., que em um outro momento das gravações canta sozinho uma canção em francês que aprendeu na sala, não responde à solicitação para que cante em albanês e aprova quando a professora conclui: "isso não existe em albanês".

Pode-se fazer a hipótese de que, para S., a falta de competência em francês está diretamente relacionada à sua competência em albanês (não sei falar francês porque sou albanófono) e que isso explica sua recusa não apenas de ser categorizado como locutor não experiente em francês, mas também como locutor experiente em outras línguas, mesmo se esta categorização possa ser sentida, por outras crianças que não têm a mesma insegurança em francês, como valorizante.

\subsection{Identidade de um aluno regularmente reafirmada}

S., em compensação, participa com muito boa vontade de muitas atividades que contribuem para lhe conferir um estatuto idêntico ao de seus colegas de sala. Nas aulas de matemática ou de francês, participa ativamente e a professora deve lembrá-lo de "levantar o dedo". Ele responde às vezes de maneira fantasiosa, o que dá a impressão de que ele mais quis participar do que responder ao que foi solicitado. Participa regularmente das trocas verbais que acontecem a cada volta da recreação, em que os alunos podem falar das discussões e briguinhas que tiveram com seus colegas. Durante essas trocas, mesmo se não foi diretamente mencionado, S. está sempre bastante atento. Ele se defende se percebe que falam dele, se desculpa quando a professora lhe pede para fazê-lo, mas também toma espontaneamente a palavra, como nessa interação de 23 de março, em que, assim que voltaram para sala, S. e um outro de seus colegas levantaram a mão, antes mesmo que todos os colegas estivessem sentados:

Olh@res, Guarulhos, v. 1, n. 2, p. 100-119, Novembro, 2013. 


\section{Recorte 1: Retorno do recreio - 23 de março ${ }^{12}$}

1. P.: S., você tinha algo a dizer?

2. S.: Bachir, ele disse bebê (para ?) mim.

3. Alunos: <risadinhas>

4. P.: Não... Mas... não estou vendo graça nisso, porque isso não tem graça pra $\mathrm{S}$.

5. Bachir: Eu não the disse isso, eu disse pra mim mesmo

6. P.: Peça desculpas, porque aparentemente S. pensou que era pra ele. Então, você explica pra ele.

7. Bachir: Você pode me desculpar?

8. P.: Você tá vendo! Aparentemente, ele tá zangado. Explica o que aconteceu.

9. Bachir: Não disse isso pra você.

10. P.: S., Ouviu o que ele disse?

11. Bachir: Não disse pra você, $S$.

12. S.: Se ele disse mim (aqui/se?) Bachir disse mim.

A atitude extremamente atenta de S. (e, em geral, de toda a sala) durante essas interações mostra que ele compreendeu o que estava em jogo em termos do cotidiano da classe. Segundo o que foi contado por duas professoras, S. foi frequentemente atacado desde o início das aulas, pois tinha, nos primeiros meses, um comportamento considerado agressivo por seus colegas. No momento em que começamos nossas observações, não somente as queixas estavam menos frequentes, mas também vimos vários colegas defendê-lo espontaneamente quando Bachir, na semana seguinte, acusou S. de ter lhe dado uma bofetada.

\footnotetext{
${ }^{12}$ CONVENÇÕES DE TRANSCRIÇÃO

<em voz baixa>entre < > : descrição de elementos paraverbais ou não-verbais.JOGOSAs maiúsculas indicam que uma ou mais sílabas foram evidenciadas por um acento de intensidade.+pausa $(++/+++$ pausas mais longas). Acima de 5", a duração é indicada entre parênteses $\square$ A curva entonativa do grupo rítmico é globalmente ascendente.ma :A sílaba é alongadaXXXSequência inaudível, o número de $\mathrm{X}$ correspondente aproximadamente ao número de sílabasXX (Você vem ?)Sequência reconstituída e da qual o transcritor não tem certeza. A : assim eu. A : é isso. As palavras assinaladas indicam a parte dos enunciados que se encavalam $P$ desde sempre $=\mathrm{A}=$ SIMA encadeia imediatamente, sem a menor pausa, sobre a fala de P.[gest]Transcrição fonética
}

Olh@res, Guarulhos, v. 1, n. 2, p. 100-119, Novembro, 2013. 


\subsection{A emergência de uma consciência de aprendizagem e a entrada na comunidade dos locutores francófonos}

A recusa de ver seu plurilinguismo tematizado nas interações da sala pode ser esclarecida pelas interações que aconteceram fora da sala de aula e em que S. teve oportunidade de falar ou não de sua relação com as línguas e a aprendizagem. Durante a conversa que organizamos com seus professores e uma intérprete para explicar aos pais de $\mathrm{S}$. o sentido das observações que tínhamos começado e solicitar-lhes a autorização para gravação, eu tinha, ingenuamente, perguntado para S. se ele tinha a impressão de ter feito progressos desde a sua chegada na França. Como ele não respondia, o intérprete traduziu e S., sempre mudo, apertou sua mãe com um sorriso incomodado. Minha pergunta visivelmente não fazia sentido para ele.

No início do mês de junho, dois alunos armênios, principiantes, chegaram na escola. As aulas para os alunos alófonos foram reorganizadas. Nora, mais velha, originária de um país da África francófona e escolarizada na França, naquele momento, há mais de dezoito meses, deixou o curso e S. se encontrou na posição de "locutor experiente" com relação a seus dois novos colegas. A professora encarregada desses cursos de francês como segunda língua me contou que, no início da primeira aula com os dois alunos armênios, $\mathrm{S}$. sussurrou em seus ouvidos, com um grande sorriso: "Eles são como eu", depois, ao final da aula "Eles não sabem falar francês". Assisti à segunda aula com os dois alunos armênios. Quando soava a sirene de um caminhão de bombeiro, a professora aproveitou o momento para introduzir e/ou lembrar um pouco de vocabulário. S. começou a contar uma intervenção de bombeiro que ele tinha visto no dia anterior. A complexidade e a duração da sua história constrastavam fortemente com as intervenções rápidas que eu tinha ouvido até aquele momento. S. excluiu, assim, as duas crianças armênias da interação para formar, momentaneamente, uma

Olh@res, Guarulhos, v. 1, n. 2, p. 100-119, Novembro, 2013. 
comunidade de interlocutores francófonos com sua professora e comigo.

$\mathrm{O}$ que nos revelam os discursos (e os silêncios) de $\mathrm{S}$. é que, único aluno não francófono na escola até a chegada dos dois alunos armênios, ele tinha dificuldades para construir uma "escala" que lhe permitisse mensurar a evolução de sua competência linguística. A chegada das duas crianças não-francófonas torna palpáveis para S. os níveis inferiores ao que, naquele momento, tinha atingido em sua competência com relação ao francês. Esse acontecimento resgata, provavelmente, o estado de isolamento linguístico do qual saiu. Pelos dois comentários que fez sobre seus colegas récem-chegados e pela conversa que tem com seus dois parceiros francófonos, ele mostra que é capaz, naquele momento, de conciliar sua identidade de não-nativo, de aprendiz e de membro da comunidade francófona. Neste espaço protegido que é o da classe de apoio linguístico, vai poder se categorizar ao mesmo tempo "como eles", sentindo-se menos isolado em suas dificuldades diante do francês, mas também como um locutor francófono capaz de conduzir uma conversa e de ser compreendido por esses interlocutores nativos.

\section{Um trabalho de apropriação discreto}

Se ele participa ativamente das interações didáticas nas aulas de aprendizagens matemáticas ou de leitura-escrita, é mais frequentemente para responder às questões da professora e suas intervenções se limitam, portanto, a respostas de uma ou duas palavras que aparecem entre a pergunta e a avaliação da professora (cf. estrutura de interação ternária estudada por Sinclair e Coulthard, comentada particularmente em BANGE, 1992). Vimos, no primeiro recorte, um exemplo de tomada de fala mais complexo, durante uma discussão na volta da recreação. Se há de fato estratégia de comunicação da parte de S. para convencer de sua boa fé no turno 12, não há estratégia de aprendizagem (por exemplo, não há retomada do

Olh@res, Guarulhos, v. 1, n. 2, p. 100-119, Novembro, 2013. 
dado de Bachir, que, em 11, emprega o verbo "dizer" acompanhado da preposição "para"13), provavelmente porque o desafio comunicativo é demasiadamente intenso para que S. pudesse dedicar a "atenção particular" necessária para uma estratégia de aprendizagem ser "em parte buscada por si só" e pudesse, assim, ter por resultado "a aquisição" de novos meios de comunicação em L2 (BANGE, 1992, p.64). Entre as interações em que, para fazer seu papel de aluno, S. só precisa participar com algumas palavras isoladas e as interações em que todo o seu ser está implicado, é dada prioridade à busca da meta comunicativa, não deixando espaço para qualquer trabalho metalinguístico. Pode-se perguntar, então, quais são as interações, em um dia de escola, que favorecem o compromisso de S. na exploração e no desenvolvimento de sua competência linguística.

\subsection{Aquém e além da zona de desenvolvimento proximal ${ }^{14}$}

WILLET (1995, p.481) nota, na sala que observou, que depois de algumas semanas, um observador exterior não é mais capaz de distinguir as crianças récem-chegadas das crianças anglófonas porque "se pedia às crianças inglês segunda língua o mesmo que às crianças linguisticamente experientes: elas realizavam as mesmas tarefas, seguiam as mesmas regras e utilizavam o mesmo material". O mesmo acontece com S. No entanto, por vezes, relaxa completamente sua atenção nas interações que inflamam seus colegas, e isso porque lhe faltam conhecimentos ao mesmo tempor referenciais e linguísticos para acompanhar, nem que seja globalmente, as trocas que se desenvolvem. É assim em interações de preparação para a "aula

\footnotetext{
${ }^{13}$ Nota dos Trad. Em francês, ele não retoma a preposição A, solicitada pelo verbo DIRE. O que a autora aponta é, portanto, que S. não se apropria da estrutura sintática verificada, dizendo "Bachir disse mim" ao invés de "Bachir disse para mim".

${ }^{14}$ Lembremo-nos de que o conceito desenvolvido por VYGOTSKI é definido como o que a criança "sabe fazer hoje em colaboração" e que ele "saberá fazer amanhã sozinho". Esta zona, que "determina as possibilidades de aprendizagem" (VYGOTSKI, 1997, p.355-356), é delimitada por um limite inferior (abaixo do qual se encontra o que a criança sabe fazer sozinha) e um limite superior, para além do qual se encontra o que a criança não pode ainda fazer, mesmo com a ajuda de um adulto.
}

Olh@res, Guarulhos, v. 1, n. 2, p. 100-119, Novembro, 2013. 
verde" 15 ou de preparação de um encontro esportivo inter-escolas. Durante essas interações, S. parece "sonhar". O contraste é importante com as atividades rituais, das quais, como já dissemos, S. participa ativamente. Ao final do ano escolar, ele está, inclusive, mais atuante do que alguns colegas para o ritual da data, que consiste em dizer, em um formato de frase imposta, a data do dia anterior, a data do dia e a data do dia seguinte. Se a aprendizagem dessas frases provavelmente contribuíram, nos primeiros meses, para o armazenamento de "expressões modelos" que são conhecidas como uma das fases de aquisição em crianças, parece bem que, no final do ano, sua participação entusiasta nestas atividades não tem mais do que uma função socializante.

Entre as interações que estão para além de sua capacidade de linguagem, porque as temáticas desenvolvidas são muito desconectadas do contexto imediato ou dos temas recorrentes da aula e as interações altamente ritualizadas que, ao final do ano letivo, só solicitam de $\mathrm{S}$. intervenções localizadas abaixo de sua zona de desenvolvimento proximal, há toda uma gama de interações que lhe permitem explorar os micro-sistemas de sua interlíngua.

\subsection{As interações de jogo}

Quando eles terminaram uma atividade e a professora está ocupada com alunos de $\mathrm{CE} 1^{16}$, os alunos de $\mathrm{CP}$ têm o direito de brincar com jogos de tabuleiro. S. frequentemente toma a iniciativa de propor partidas de xadrez ou de outros jogos do tipo dominó. Essas situações regradas, em que os desafios são imediatos, ao mesmo tempo reais e limitados, constituem um espaço propício às atividades linguageiras de apropriação. Assim, em 20 de junho, quando sua colega come seu peão em uma partida de xadrez dizendo "Eh, bem,

\footnotetext{
${ }^{15}$ Nota dos Trad. A "aula verde" (classe verte) é uma saída escolar durante a qual os alunos partem em descoberta da natureza sem os pais, mas acompanhados pelos professores.

${ }^{16}$ Nota dos Trad. Sigla para Curso Elementar primeiro ano. Vem logo após o CP.

Olh@res, Guarulhos, v. 1, n. 2, p. 100-119, Novembro, 2013.
} 
tchau tchau", ele, por sua vez, come uma peça repetindo o que se apropriou da expressão: "Eh tchau tchau tchau". Muitas vezes, instalando seus peões brancos (sua cor favorita) para uma partida de xadrez, ele comenta a ausência de um peão que foi substituído, na caixa, por um peão diferente daqueles do jogo, já que de cor preta. Em 30 de março, ele disse colocando o peão no tabuleiro: "não é branco" $"$. Em 01 de junho, ele participou de um jogo de cartas com Amal que tenta, em vão, fazer com que $\mathrm{S}$. baixe, de suas cartas, as que tinham um pequeno logotipo com uma casa vermelha. Ela lhe pergunta se ele tem ainda cartas como essa, lembrando-lhe que ela baixou uma, e enfatiza o fato de que ela mesma não tem mais cartas assim e que ele, certamente, tem outras. S. está disposto a admitir que tem cartas com casas, mas não com "casas vermelhas".

\section{Recorte 2: Jogo, tempo livre - 01 de junho}

1. A.: eu, eu não tenho mais com esse negocinho vermelho embaixo

2. S.: X

3. A.: $\mathrm{X}$ casa casinhas vermelhas embaixo aqui, você, você tem muitas. Você sabe $\mathrm{X}$ (quantas?) Eu estou vendo aqui. Tem casinhas vermelhas.

4. S.: Aqui tem casinhas vermelhas isso isso isso

5. A.: olhe as casinhas vermelhas

6. S.: Sim, mas eu não tenho vermelha, eu aqui

7. A.: Eu só tenho uma

8. S.: < olha uma a uma suas cartas tranquilamente > mas isso, uh, não é + vermelho + vermelho + isso não é vermelho + isso não é vermelho + isso isso não é vermelho + isso não é vermelho + isso não é vermelho.

Além da repetição no turno 4, que talvez seja a manifestação de algo que foi compreendido, parece interessante nos atermos na série de auto-retomadas na intervenção 8. A auto-reformulação que intervém é muito marcante, pois corresponde a uma modificação para se obter maior conformidade com a norma linguística e não deixa de lembrar o auto-apoio mencionado por Pallotti (2005, p.115). Deve-se notar, porém, que nada na entonação sugere um trabalho de auto-reparação. Nada permite afirmar que o reajustamento em direção à

\footnotetext{
${ }^{17}$ Nota dos Trad. Vale observar que, em francês, o que S. disse foi "est pas blanc", quando deveria ter colocado, no enunciado, o pronome Il diante do verbo (Il est pas blanc).

Olh@res, Guarulhos, v. 1, n. 2, p. 100-119, Novembro, 2013.
} 
norma linguística é fruto de um trabalho consciente, mas esses três recortes, dentre muitos outros que podemos mencionar, atestam uma atividade de linguagem intensa durante os momentos de jogo. Poderíamos aproximar essas sequências de outras passagens de interações bastante lúdicas em que $\mathrm{S}$. parece explorar as zonas instáveis de sua interlíngua.

Em 23 de março, S., organizando-se para a recreação, disse com satisfação "biblioteca minha + + biblioteca". Ele evoca, assim, para si, a pequena biblioteca de 14 livros, denominada assim pela professora, que esta lhe fez fazer ao lado de sua mesa durante a correção coletiva de um problema de matemática, em que era preciso subtrair 5 livros de 14 livros. Em 30 de março, é o dia de S. cuidar da organização da aula. Cada uma das tarefas que lhe são atribuídas torna-se uma oportunidade para uma atividade de linguagem. Antes de colocar uma folha na frente de cada um de seus colegas, ele disse "uma folha" (às vezes, acompanhado do nome do colega). Em outra distribuição, deixa a si mesmo por último e diz, em tom de brincadeira, algo que se aproxima de "quem é que não tem $\lambda$ ". Depois, repete a mesma fala, aproximando-se da mesa da professora para colocar a última folha. Um pouco mais tarde, na mesma manhã, ele recolhe os cadernos e pronuncia, a cada vez, o nome da criança (o que não é usual). Quando chega nele mesmo, diz teatralmente "e eu"18.

O que é comum a estas intervenções linguísticas, além de serem uma oportunidade para S. explorar diferentes formas de ancoragem enunciativa se apoiando nas marcas de primeira pessoa, é sua natureza não-necessária, quase gratuíta e, portanto, não arriscada. Podemos considerar essas produções de linguagem como fala

\footnotetext{
${ }^{18}$ Ficamos tentados em aproximar estes enunciados do comentário que S. fez no mesmo dia enquanto começou um jogo de construção com Amal (que, no início, não era para ser um jogo competitivo). Uma primeira vez, ele declara "pronto" seguido rapidamente por "eu terminado" [Nota dos Trad. Em francês, ele diz ma fini, o que remeteria ao moi fini]. Depois, mostrando as duas construções: "você segundo, eu primeiro" [Nota dos Trad. Aqui, uma vez mais, ele diz ma premier]. Estes enunciados aproximam-se dos precedentes do ponto de vista dos micro-sistemas da interlíngua explorados, mesmo se se afastam destes mesmos enunciados pelo fato de que têm um destinatário evidente.
}

Olh@res, Guarulhos, v. 1, n. 2, p. 100-119, Novembro, 2013. 
egocêntrica, mesmo se elas não têm um destinatário evidente. Com efeito, o simples fato de que ocorrem em francês mostra que participam de uma prática de linguagem social. Certo, nada garante que essas práticas de linguagem permitirão uma aproximação da competência linguística de S. da dos falantes nativos, mas é difícil não ver nesta relação gratuíta, lúdica, à língua, e, ao mesmo tempo, muito focada em termos de micro-sistemas postos em prática, algo semelhante a uma estratégia de aprendizagem. Vê-se, portanto, que a análise dos vínculos entre estratégias de aprendizagem e estratégias de comunicação que apresentava o fato de se "assumirem riscos" como "uma condição necessária para que o locutor não-nativo se torne um candidato aprendente" (BANGE, 1992, p.67) deve ser minimizada.

\subsection{A exploração sistemática dos empregos de um item}

Em um contexto menos lúdico, com desafios comunicativos imediatos, mas de modo igualmente (se não mais) sistemático, $\mathrm{S}$. explora os empregos possíveis da expressão "ou o quê" ( $c f$. recortes 3 e 4 infra, 08 e 09 de junho). Essas três ocorrências próximas de "ou o quê" nos mostra, de um lado, que ele identificou corretamente a expressão e que é capaz de reconstitui-la, de outro, que as condições de emprego dessa expressão não estão claramente fixadas, já que, apenas na intervenção 1 do recorte 3 , ela é de fato conforme a um emprego de um falante nativo.

Olh@res, Guarulhos, v. 1, n. 2, p. 100-119, Novembro, 2013. 


\section{Recorte 3: Preparação para "aula verde" - 08 de junho}

$<$ S tenta atrair a atenção de sua vizinha concentrada em um caderno. Ele a chama>

1. S.: Amal Amal Amal você não me entende $\pi \square$ Você não me entende ${ }^{19} \lambda$ Você não me entende ou o quêr

$<$ Alguns minutos mais tarde: S. se voltou para uma colega sentada atrás dele. A professora fez a chamada e, quando chega em seu sobrenome, insiste nele.>

2. S.: Sim disse $\operatorname{sim}=$

3. P.: = Tudo bem, mas eu estou te chamando também para que + você se +

4. A.: vire

(...)

7. S.: Por quê

8. P.: Porque na sala, $\mathrm{S}$. lembra para mim a regra

9. S.: trabalho ou o quê

10. P.: Nós trabalhamos, sim

\section{Recorte 4: Correções - 09 de junho}

Os alunos trabalham sozinhos, enquanto P. verifica os papéis para a aula verde.

$\mathbf{S}$ <para os colegas próximos ou para si mesmo> "eu, eu terminei ou o quê".

Poderíamos simplesmente concluir que há uma sobregeneralização do emprego de "ou o que", ao qual S. parece atribuir uma função comunicativa bastante ampla, próxima daquela de "não é". No entanto, S. usa três vezes a expressão em três horas de gravação feita nesses dois dias, misturando momentos em que efetivamente se arrisca (particularmente na intervenção 10 do recorte 2, em que os riscos não são apenas da ordem do malentendido) e a exploração mais mais próxima das formas de linguagem quase que auto-dirigidas evocadas em 2.2. Isto nos convida a concluir que há um "trabalho" sistemático de tipo estratégico.

\footnotetext{
${ }^{19}$ A entonação e o contexto permitem fazer a hipótese que ele quer lhe perguntar se ela o compreende.

Olh@res, Guarulhos, v. 1, n. 2, p. 100-119, Novembro, 2013.
} 


\section{Quando o papel de aluno e o papel de aprendiz de língua se} encontram: as identidades reconciliadas

Mostramos alguns aspectos das dificuldades que S. encontrava para assumir seu estatuto de aluno plurilíngue (negação de sua competência em albanês). Fizemos a hipótese de que esta recusa era devida provavelmente ao fato de que seu estatuto de aluno plurilíngue convocava, sem dúvida, a seus olhos de maneira imperiosa, uma outra dimensão de sua identidade que ele não queria ver tematizada nas interações, a saber, a de aluno não-francófono, de aluno aprendiz de francês, de aluno menos experiente em francês. Vimos também que essas negações não impediam S. de desenvolver sua competência linguística em francês e estudamos alguns dos lugares interacionais que parecem contribuir para suas aprendizagens linguísticas. Gostaríamos de terminar este estudo com um recorte da gravação coletada durante a nossa penúltima visita.

Neste dia, foi Bachir, figura importante do grupo de alunos de CE1, o responsável por ler o cardápio. Após oito interações para ajudar Bachir a ler a palavra "rilletes" 20 K. intervém, interrompendo a professora:

\section{Extrato 5: Leitura do menu - 08 de junho de 2006 -}

1. K.: eu eu sei o que o que é "rillette"

2. S.: eu não, eu não + + eu não

3. As + P.: <brouhaha>

4. P.: Ao mesmo tempo que Bachir fala, vocês escutam também einh?

5. S. Eu não $\lambda \mathrm{Eu}$

6. P.: você sabe o que é "rillettes" =

7. $\mathrm{S} .:=$ não

\footnotetext{
20 Nota dos Trad. Especialidade francesa que se assemelha a um patê com carne em pedaços, feito de carne de porco ou outros tipos de carne, misturadas ou não.

Olh@res, Guarulhos, v. 1, n. 2, p. 100-119, Novembro, 2013.
} 
A intervenção de K. em 1, que categoriza uma parte da sala - em todo caso, categoriza Bachir ${ }^{21}$ - como não sabendo o que são "rillettes", permite a $S$. de se categorizar, por sua vez, como não sabendo também o que é isso (eu não repetido três vezes). Certo, há uma ambiguidade nesta passagem sobre o que é desconhecido para os alunos (a palavra e/ou seu referente), mas é notável que S. aproveite desta ambiguidade para dizer, pela primeira vez em nosso corpus, que não conhece uma palavra. Saber dizer que não sabemos faz parte das competências do papel do aluno e é muito mais fácil "confessar" quando se vê que não se está sozinho. Neste contexto particular, que intervém no mês de junho, S., que adquiriu uma certa segurança linguística, parece encontrar um meio de conciliar a sua identidade de aluno da sala de CP-CE1 e sua identidade de aprendiz de língua.

Construir seu lugar nas interações de uma sala de alunos francófonos, quando se é o único aluno alófono, certamente não é uma tarefa fácil. A frequentação assídua em cursos específicos para alunos nãofrancófonos permite se categorizar legitimamente como "aprendiz de língua”, perceber seu avanço - graças, sobretudo, à chegada de outros alunos iniciantes em francês - e se envolver em intervenções de maior duração. Tudo isso se deve ao ambiente específico dessa classe, ao mesmo tempo mais "seguro" e mais aberto às conquistas metalinguísticas do que o de uma classe regular.

O estudo das interações em classes regulares revela, no entanto, múltiplas ocasiões para a criança alófona de conjugar aprendizagens escolares, socialização escolar e socialização linguística. A riqueza da articulação entre essas diferentes formas de engajamentos na interação delineada por este estudo convida a continuar a observação deste modo de integração escolar das crianças recém-chegadas.

\footnotetext{
${ }^{21}$ É possível que o fato de Bachir não comer carne de porco nas refeições contribua para a reação de K., que supõe, talvez, existir um vínculo entre esta prática alimentar e o desconhecimento desse alimento.

Olh@res, Guarulhos, v. 1, n. 2, p. 100-119, Novembro, 2013.
} 
O aluno com pouco domínio na língua da escolarização: convergência ou concorrência da socialização linguageira e da socialização escolar?

\section{Referências bibliográficas}

ARDITTY, Jo . Approches interactionnistes : exemples de fondements théoriques et questions de recherche, Le Français dans le Monde, Recherches et Application, Les interactions en classe de langue, 2005.

BANGE, Pierre. A propos de la communication et de l'apprentissage en L2, notamment dans ses formes institutionnelles, AILE 1, 53-58, 1992.

GAJO, Laurent et MONDADA, Lorenza. Interactions et acquisitions en contexte, Fribourg, Editions universitaires de Fribourg, 2000.

PALLOTTI, Gabriele. Variations situationnelles dans la construction des énoncés en L2 : le cas des autorépétitions, AILE 22, Interaction et diversité des conduites d'apprentissage, 2005.

RIVIERE, Véronique. Aujourd'hui nous allons travailler sur..., Le Français dans le Monde, Recherches et Application, Les interactions en classe de langue, 2005.

VASSEUR, Marie Therèse. En CLIN, l'apprentissage du français passe par la socialisation langagière, LINX, 49, Acquisition et communication en langue étrangère: Interlangue et communication exolingue / endolingue, Nanterre, 125-140, 2003.

VYGOTSKI, Lev S. Pensée et langage, La dispute, Paris, 1997.

WILLETT, Jerri. Becoming First Graders in an L2 : An Ethnographic Study of L2 socialization, TESOL Quarterly Vol. 29, 473-503, 1995.

\section{Tradutores}

Texto traduzido por Márcia Romero (Universidade Federal de São Paulo) e Thatiana Ribeiro Vilela (Universidade Federal de São Paulo).

Olh@res, Guarulhos, v. 1, n. 2, p. 100-119, Novembro, 2013. 
Violaîne Bigot ${ }^{1}$

Universidade Sorbonne Nouvelle

\section{Resumo}

Este relato etnográfico descreve a participação de S., criança de sete anos de idade e falante não-nativa de língua francesa, nas interações cotidianas em sala de aula. Os dados foram coletados ao longo de cinco meses em classe regular, à qual $\mathrm{S}$. foi integrado, bem como no curso de francês língua estrangeira, por ele frequentado, algumas horas por semana, com outros alunos não-nativos. $\mathrm{O}$ estudo busca mostrar como o desenvolvimento de sua competência comunicativa (ou, mais amplamente, sua socialização em L2) compete com e/ou ajuda, e/ou é ajudado pelo desenvolvimento de outros aprendizagens e por sua socialização escolar.

Palavras-chave: Socialização em L2; Socialização escolar; Aprendizagens escolares; Competência comunicativa em L2; $\quad$ Aquisição em L2.

1 Docente da Universidade Sorbonne Nouvelle - Paris 3. Email: violaine.bigot@univparis3.fr. Texto traduzido por Márcia Romero e Thatiana Ribeiro Vilela. Artigo originalmente publicado sob o título "L'enfant nonfrancophone scolarisé dans une classe ordinaire : convergence ou concurrence de la socialisation langagière et de la socialisation scolaire ?", in. CANDELIER et al. (eds.): Conscience $d u$ plurilinguisme. Presses Universitaires de Rennes, 2008. Sob o aval da autora, o título do artigo em português foi readequado por sugestão dos tradutores.

Olh@res, Guarulhos, v. 1, n. 2, p. 100-119, Novembro, 2013. 


\title{
PUPILS WITH LITTLE MASTERY OF THE LANGUAGE OF SCHOOLING: CONVERGENCE OR CONFLICT BETWEEN LANGUAGE SOCIALIZATION AND SCHOOL SOCIALIZATION
}

\begin{abstract}
This ethnographic report describes the participation of $\mathrm{S}$, a seven year old non-native speaker child, in the daily classroom interactions of his class. Data were collected over five months. in the "ordinary" classroom where he was integrated as well as in the "special needs" course he attends a few hours a week with other non-native pupils. The study aims at showing how the development of his communicative competence (or more widely, his "L2 socialization) compete with and/or help, and/or is helped by the development of other learnings and of his scholar socialization.
\end{abstract}

Keywords: L2 socialization; Scholar socialization; Scholar learnings; L2 communicative competence; L2 acquisition. 


\section{Contexto de estudo e questões iniciais}

Muitas pesquisas de tipo etnográfico, fundamentadas, como a nossa, em análises de interações verbais em sala de aula, permitiram, nos últimos anos, avançar na compreensão do desenvolvimento das trocas verbais das quais participam as crianças e os adolescentes "alófonos",2 nos primeiros meses de sua escolarização (ver, particularmente, GAJO e MONDADA 2000, VASSEUR 2003, RIVIERE 2005). Nosso estudo inscreve-se nesta perspectiva, mas se interessa por um modo de integração diferente que tende a se desenvolver e que consiste em escolarizar as crianças, desde a sua chegada na França, em classes "regulares". Essa forma de escolarização pouco foi estudada por pesquisas etnográficas no contexto francês ${ }^{3}$.

Assim, na academia de Nantes $^{4}$, a maioria das crianças e dos adolescentes, se tiveram uma escolarização normal antes de sua chegada na França, é direcionada para as classes regulares. Eles só têm um apoio linguístico verdadeiramente específico algumas horas por semana, em que trabalham com uma professora especializada. Com este acolhimento, a integração escolar da criança parece privilegiada: o que lhe é solicitado é, antes, que aprenda o seu "papel de estudante" no sistema educativo francês, que construa as mesmas aprendizagens que as crianças francesas, postulando-se que "a intendência linguística" ${ }^{, 5}$ acontecerá normalmente. O estudo de caso

\footnotetext{
${ }^{2}$ Nota dos Trad. Pessoa cuja língua materna é diferente daquela da comunidade em que vive.

3 Alguns estudos foram realizados fora do contexto francês. Podemos citar particularmente o estudo de WELLET (1995), que trata de uma sala mista (5 alunos alófonos em uma sala com 22 alunos) em uma escola internacional de um campus universitário norte-americano e o estudo de PALLOTTI (2005) sobre a socialização linguageira de uma aluna marroquina em uma escola italiana de educação infantil.

4 Nota dos Trad. Na França, a academia constitui uma divisão territorial e administrativa da Universidade, que agrega um conjunto de estabelecimentos e de professores de ensino público de todos os níveis. Nantes, por sua vez, é uma cidade francesa.

${ }^{5}$ Nota dos Trad. Expressão que parece se apoiar na fala do general De Gaulle, que teria afirmado, por volta de 1958, L'intendance suivra toujours, querendo dizer que os problemas econômicos e financeiros do Estado terminam sempre por serem resolvidos, por bem ou por mal. No presente contexto, o que se postula é que se espera que os problemas linguísticos sejam resolvidos normalmente.
}

Olh@res, Guarulhos, v. 1, n. 2, p. 100-119, Novembro, 2013. 
O aluno com pouco domínio na língua da escolarização: convergência ou concorrência da socialização linguageira e da socialização escolar?

apresentado a seguir se propõe a examinar este desafio educativo em uma perspectiva sócio-interacionista centrada nos processos de apropriação da linguagem.

No âmbito das diferentes observações, conduzidas em campo na cidade de Angers, em classes de integração e de acolhimento $^{6}$, acompanhei durante cinco meses um garoto albanês, doravante S., chegado na França em outubro de $2005^{7}$. Com idade de seis anos, foi escolarizado desde a sua chegada em uma sala de ciclo 2 de uma área de educação prioritária chamada de "ambição-êxito". Eu o encontrei, observei e gravei, antes, nos cursos de francês língua estrangeira que ele tinha três vezes por semana com outra aluna, Nora. Depois, entre março e junho de 2006, passei por volta de trinta horas em sua sala (três observações por mês em média) e recolhi por volta de quinze horas de gravações ${ }^{8}$.

Vamos examinar, por meio da análise das trocas verbais das quais $\mathrm{S}$. participa, a maneira como ele se categoriza ou não como bilingue, alófono, aprendiz. Veremos também, por meio desse estudo de caso, que, entre as interações de grandes desafios comunicacionais e certas interações perfeitamente rotinizadas (rituais de datas, etc.), existe toda uma gama de interações que lhe oferecem a ocasião de explorar, às vezes de maneira muito sistemática, diferentes dimensões

\footnotetext{
${ }^{6}$ Nota dos Trad. Uma classe de acolhimento, no original Classe d'accueil (CLA), é um curso de francês como segunda língua oferecido em uma escola da Educação Nacional. Os alunos são conduzidos a esta classe pelo Centro acadêmico para a escolarização das crianças alófonas recém-chegadas (CASNAV) de sua academia.

${ }^{7}$ S. chegou com seus pais e sua irmã menor. Seus pais são não-francófonos no momento de sua chegada na França. Sua mãe fala apenas albanês. Seu pai, pedreiro, especializado na restauração de edifícios, fala também macedônio, língua de sua cidade. A família mora em um centro de solicitantes de asilo situado próximo da escola. S. segue seus estudos com assiduidade. Ele participa com seus pais das atividades extracurriculares oferecidas às famílias pela escola depois do horário de aula.

${ }^{8}$ De acordo com a professora, reservei momentos de observação participante, em que trabalhava com o grupo de alunos do curso preparatório do qual fazia parte S. enquanto a professora trabalhava com os alunos do curso elementar, primeiro ano. Eu era muito solicitada pelos alunos, que quase não me deixavam disponível para "observar". Esses momentos tinham, entre outros objetivos, o de permitir a médio prazo que minha presença fosse aceita pelas crianças para que eu pertubassse o menos possível a sala durante o tempo de observação não-participante. Que todos os adultos e crianças que aceitaram e facilitaram a minha presença na sala sejam aqui agradecidos. Agradeço também a Jo Arditty, que, mais uma vez, me incentivou e apoiou com sua leitura de uma primeira versão deste artigo.
}

Olh@res, Guarulhos, v. 1, n. 2, p. 100-119, Novembro, 2013. 
de sua competência linguística, diferentes micro-sistemas de sua interlíngua.

\section{Uma identidade plurilíngue mantida à distância}

\subsection{Centração do professor nas tarefas de aprendizagem}

Nas sequências de aprendizagem dessa classe regular, as focalizações metalinguísticas são pouco numerosas e mesmo quando, de nosso ponto de vista de observadora e familiarizada com aulas de língua, nos parecia evidente que a incapacidade de $\mathrm{S}$. em realizar uma atividade estava ligada a um problema de compreensão do que lhe era solicitado, as trocas verbais não apresentavam as características de bifocalização descritas por BANGE (1992).

Para ilustrar nosso propósito com um exemplo que é deveras numeroso no corpus, podemos evocar a seguinte interação. A professora (doravante P.) pediu aos alunos que escrevessem palavras começando com a sílaba "sa" e S. propôs "maison” [casa]. Quando, logo depois, P. solicita uma palavra iniciada por "re", S. propôs "savon" [sabão], que é o exemplo que foi considerado e escrito no quadro para a sílaba "sa". Então P. The pergunta "Em SAvon, eu ouço"re"?". Uma aluna propõe "robe" [vestido]. A reposta é comentada e novamente a professora questiona S. ("Então, S. encontrou?"). Este, mais uma vez, propõe "savon" [sabão] e a professora lhe pergunta de novo: "Então, S., eu ouço "re" em “savon"?". Ora, a professora concordou, quando falamos do ocorrido, em admitir que $\mathrm{S}$., que fazia parte dos alunos de $\mathrm{CP}^{9}$ que tinham compreendido globalmente a atividade, tinha provavelmente encontrado um problema de compreensão do que lhe foi solicitado. Na sala, no entanto, ela reagia como faria com qualquer aluno francófono,

\footnotetext{
${ }^{9}$ Nota dos Trad. CP de curso preparatório, primeiro ano de ensino da escola básica francesa. Olh@res, Guarulhos, v. 1, n. 2, p. 100-119, Novembro, 2013.
} 
tentando fazer com que S comparasse a tarefa realizada com a que foi prescrita, sem chamar a atenção para o discurso de prescrição.

Os exemplos de mal-entendidos desse tipo, que não dão lugar às sequências metalinguísticas, são numerosos e, desse ponto de vista, a interação didática à qual é exposto $\mathrm{S}$. diverge da que podemos observar em classes "restritas" de tipo CLIN ou CLA ${ }^{10}$ (cf. particularmente os trabalhos de RIVIERE sobre as instruções verbais dadas em classe de acolhimento). Poderíamos ver, nessas trocas verbais, o fato de se ter perdido a ocasião de se trabalhar, em contexto, verbos frequentes como "commencer par" [começar por] ou "entendre" [ouvir], mas este não é o nosso objetivo. Com efeito, é necessário constatar:

1. que S., apesar dos frequentes mal-entendidos que barram a compreensão do que lhe é solicitado, constrói, no mesmo ritmo que seus colegas de sala, aprendizagens matemáticas e de leitura-escrita. Como veremos abaixo, perguntamo-nos sobre a existência de outros lugares interacionais, na vida da classe, favoráveis a um trabalho metalinguístico;

2. a atitude da professora aparece no momento em que S., de um lado, recusa ser categorizado nas trocas verbais como locutor nãoexperiente ou simplesmente plurilíngue e, de outro, mobiliza seus recursos linguísticos para poder participar, como os outros alunos, das trocas que fundam a vida do grupo na sala, como veremos adiante.

\subsection{Recusa de $S$ de ser categorizado como locutor não-experiente}

Se a professora, nas atividades de aprendizagem, não tematiza os problemas linguísticos que S. pode encontrar, ela o faz, entretanto, seja nas atividades nas quais o vocabulário está no coração da aprendizagem (ficha de palavras cruzadas temáticas ou descoberta de um novo texto no livro de leitura, por exemplo), seja, quase

\footnotetext{
${ }^{10}$ Nota dos Trad. CLIN são classes de iniciação para alunos não-francófonos que acabaram de chegar na França, assim como as CLA, classes de acolhimento já explicadas acima.

Olh@res, Guarulhos, v. 1, n. 2, p. 100-119, Novembro, 2013.
} 
sistematicamente, na atividade ritual de leitura, pela manhã, do cardápio. Encontramos, então, uma ou mais questões direcionadas a S. sobre sua compreensão do vocabulário. Este nunca se engaja naturalmente nessas trocas verbais que o categorizam como locutor pouco experiente. Ele procura evitar ou encurtar as sequências de explicação de vocabulário que lhe são direcionadas. Frequentemente, responde que compreendeu desde a primeira pergunta da professora. Às vezes, quando a pergunta é muito insistente ou precisa, ele admite que não compreendeu, mas, qualquer que seja a explicação que lhe é dada, ele pretende ter compreendido ${ }^{11}$. Pode-se evocar, assim, essa interação surpreendente em que a professora, depois de ter explicado o que é o trigo, pergunta para $\mathrm{S}$ se ele entendeu. S. concorda e quando a professora, para verificar, the pergunta de que cor é o trigo, ele responde rapidamente "rouge" [vermelho]. Esta atitude, que a própria professora comentou durante nossas conversas, pode ser colocada em paralelo com a recusa de $\mathrm{S}$. de ser categorizado como locutor plurilíngue.

\subsection{Recusa de $S$ de ser categorizado como locutor bilíngue}

Por duas vezes, durante minhas observações, S. mostrou bem pouca boa vontade quando suas competências como plurilíngue foram solicitadas. A professora, ao retomar o canto do galo nas diferentes línguas européias, perguntou para S. como era na Albânia. S não manifestou nenhum entusiasmo em responder a pergunta, que pareceu não compreender (o que era surpreendente, dado o contexto). Com a insistência da professora, acabou dizendo, sem nenhum entusiasmo, o termo albanês que designa o galo. Do mesmo modo, na ocasião de um aniversário, "Happy birthday to you" foi cantado pelos alunos em três

\footnotetext{
${ }^{11}$ Notamos, no entanto, que ele sabe muito bem tirar proveito de seu estatuto de alófono nas interações de jogos evidenciadas na parte 3, em que trapaceia "tranquilamente", contando com a clemência de seus colegas, ou, simplesmente, "não escutando" as observações que alguns alunos, um pouco menos "tolerantes", lhe fazem sobre as regras a serem seguidas. Temos um exemplo de estratégia de malentendido cuidadosamente preservado no final da segunda passagem, em que S literalmente não escuta a pergunta de Amal.

Olh@res, Guarulhos, v. 1, n. 2, p. 100-119, Novembro, 2013.
} 
línguas diferentes. Uma aluna de origem turca cantou em sua língua materna. S., que em um outro momento das gravações canta sozinho uma canção em francês que aprendeu na sala, não responde à solicitação para que cante em albanês e aprova quando a professora conclui: "isso não existe em albanês".

Pode-se fazer a hipótese de que, para S., a falta de competência em francês está diretamente relacionada à sua competência em albanês (não sei falar francês porque sou albanófono) e que isso explica sua recusa não apenas de ser categorizado como locutor não experiente em francês, mas também como locutor experiente em outras línguas, mesmo se esta categorização possa ser sentida, por outras crianças que não têm a mesma insegurança em francês, como valorizante.

\subsection{Identidade de um aluno regularmente reafirmada}

S., em compensação, participa com muito boa vontade de muitas atividades que contribuem para lhe conferir um estatuto idêntico ao de seus colegas de sala. Nas aulas de matemática ou de francês, participa ativamente e a professora deve lembrá-lo de "levantar o dedo". Ele responde às vezes de maneira fantasiosa, o que dá a impressão de que ele mais quis participar do que responder ao que foi solicitado. Participa regularmente das trocas verbais que acontecem a cada volta da recreação, em que os alunos podem falar das discussões e briguinhas que tiveram com seus colegas. Durante essas trocas, mesmo se não foi diretamente mencionado, S. está sempre bastante atento. Ele se defende se percebe que falam dele, se desculpa quando a professora lhe pede para fazê-lo, mas também toma espontaneamente a palavra, como nessa interação de 23 de março, em que, assim que voltaram para sala, S. e um outro de seus colegas levantaram a mão, antes mesmo que todos os colegas estivessem sentados:

Olh@res, Guarulhos, v. 1, n. 2, p. 100-119, Novembro, 2013. 


\section{Recorte 1: Retorno do recreio - 23 de março ${ }^{12}$}

1. P.: S., você tinha algo a dizer?

2. S.: Bachir, ele disse bebê (para ?) mim.

3. Alunos: <risadinhas>

4. P.: Não... Mas... não estou vendo graça nisso, porque isso não tem graça pra $\mathrm{S}$.

5. Bachir: Eu não the disse isso, eu disse pra mim mesmo

6. P.: Peça desculpas, porque aparentemente S. pensou que era pra ele. Então, você explica pra ele.

7. Bachir: Você pode me desculpar?

8. P.: Você tá vendo! Aparentemente, ele tá zangado. Explica o que aconteceu.

9. Bachir: Não disse isso pra você.

10. P.: S., Ouviu o que ele disse?

11. Bachir: Não disse pra você, $S$.

12. S.: Se ele disse mim (aqui/se?) Bachir disse mim.

A atitude extremamente atenta de S. (e, em geral, de toda a sala) durante essas interações mostra que ele compreendeu o que estava em jogo em termos do cotidiano da classe. Segundo o que foi contado por duas professoras, S. foi frequentemente atacado desde o início das aulas, pois tinha, nos primeiros meses, um comportamento considerado agressivo por seus colegas. No momento em que começamos nossas observações, não somente as queixas estavam menos frequentes, mas também vimos vários colegas defendê-lo espontaneamente quando Bachir, na semana seguinte, acusou S. de ter lhe dado uma bofetada.

\footnotetext{
${ }^{12}$ CONVENÇÕES DE TRANSCRIÇÃO

<em voz baixa>entre < > : descrição de elementos paraverbais ou não-verbais.JOGOSAs maiúsculas indicam que uma ou mais sílabas foram evidenciadas por um acento de intensidade.+pausa $(++/+++$ pausas mais longas). Acima de 5", a duração é indicada entre parênteses $\square$ A curva entonativa do grupo rítmico é globalmente ascendente.ma :A sílaba é alongadaXXXSequência inaudível, o número de $\mathrm{X}$ correspondente aproximadamente ao número de sílabasXX (Você vem ?)Sequência reconstituída e da qual o transcritor não tem certeza. A : assim eu. A : é isso. As palavras assinaladas indicam a parte dos enunciados que se encavalam $P$ desde sempre $=\mathrm{A}=$ SIMA encadeia imediatamente, sem a menor pausa, sobre a fala de P.[gest]Transcrição fonética
}

Olh@res, Guarulhos, v. 1, n. 2, p. 100-119, Novembro, 2013. 


\subsection{A emergência de uma consciência de aprendizagem e a entrada na comunidade dos locutores francófonos}

A recusa de ver seu plurilinguismo tematizado nas interações da sala pode ser esclarecida pelas interações que aconteceram fora da sala de aula e em que S. teve oportunidade de falar ou não de sua relação com as línguas e a aprendizagem. Durante a conversa que organizamos com seus professores e uma intérprete para explicar aos pais de $\mathrm{S}$. o sentido das observações que tínhamos começado e solicitar-lhes a autorização para gravação, eu tinha, ingenuamente, perguntado para S. se ele tinha a impressão de ter feito progressos desde a sua chegada na França. Como ele não respondia, o intérprete traduziu e S., sempre mudo, apertou sua mãe com um sorriso incomodado. Minha pergunta visivelmente não fazia sentido para ele.

No início do mês de junho, dois alunos armênios, principiantes, chegaram na escola. As aulas para os alunos alófonos foram reorganizadas. Nora, mais velha, originária de um país da África francófona e escolarizada na França, naquele momento, há mais de dezoito meses, deixou o curso e S. se encontrou na posição de "locutor experiente" com relação a seus dois novos colegas. A professora encarregada desses cursos de francês como segunda língua me contou que, no início da primeira aula com os dois alunos armênios, $\mathrm{S}$. sussurrou em seus ouvidos, com um grande sorriso: "Eles são como eu", depois, ao final da aula "Eles não sabem falar francês". Assisti à segunda aula com os dois alunos armênios. Quando soava a sirene de um caminhão de bombeiro, a professora aproveitou o momento para introduzir e/ou lembrar um pouco de vocabulário. S. começou a contar uma intervenção de bombeiro que ele tinha visto no dia anterior. A complexidade e a duração da sua história constrastavam fortemente com as intervenções rápidas que eu tinha ouvido até aquele momento. S. excluiu, assim, as duas crianças armênias da interação para formar, momentaneamente, uma

Olh@res, Guarulhos, v. 1, n. 2, p. 100-119, Novembro, 2013. 
comunidade de interlocutores francófonos com sua professora e comigo.

$\mathrm{O}$ que nos revelam os discursos (e os silêncios) de $\mathrm{S}$. é que, único aluno não francófono na escola até a chegada dos dois alunos armênios, ele tinha dificuldades para construir uma "escala" que lhe permitisse mensurar a evolução de sua competência linguística. A chegada das duas crianças não-francófonas torna palpáveis para S. os níveis inferiores ao que, naquele momento, tinha atingido em sua competência com relação ao francês. Esse acontecimento resgata, provavelmente, o estado de isolamento linguístico do qual saiu. Pelos dois comentários que fez sobre seus colegas récem-chegados e pela conversa que tem com seus dois parceiros francófonos, ele mostra que é capaz, naquele momento, de conciliar sua identidade de não-nativo, de aprendiz e de membro da comunidade francófona. Neste espaço protegido que é o da classe de apoio linguístico, vai poder se categorizar ao mesmo tempo "como eles", sentindo-se menos isolado em suas dificuldades diante do francês, mas também como um locutor francófono capaz de conduzir uma conversa e de ser compreendido por esses interlocutores nativos.

\section{Um trabalho de apropriação discreto}

Se ele participa ativamente das interações didáticas nas aulas de aprendizagens matemáticas ou de leitura-escrita, é mais frequentemente para responder às questões da professora e suas intervenções se limitam, portanto, a respostas de uma ou duas palavras que aparecem entre a pergunta e a avaliação da professora (cf. estrutura de interação ternária estudada por Sinclair e Coulthard, comentada particularmente em BANGE, 1992). Vimos, no primeiro recorte, um exemplo de tomada de fala mais complexo, durante uma discussão na volta da recreação. Se há de fato estratégia de comunicação da parte de S. para convencer de sua boa fé no turno 12, não há estratégia de aprendizagem (por exemplo, não há retomada do

Olh@res, Guarulhos, v. 1, n. 2, p. 100-119, Novembro, 2013. 
dado de Bachir, que, em 11, emprega o verbo "dizer" acompanhado da preposição "para"13), provavelmente porque o desafio comunicativo é demasiadamente intenso para que S. pudesse dedicar a "atenção particular" necessária para uma estratégia de aprendizagem ser "em parte buscada por si só" e pudesse, assim, ter por resultado "a aquisição" de novos meios de comunicação em L2 (BANGE, 1992, p.64). Entre as interações em que, para fazer seu papel de aluno, S. só precisa participar com algumas palavras isoladas e as interações em que todo o seu ser está implicado, é dada prioridade à busca da meta comunicativa, não deixando espaço para qualquer trabalho metalinguístico. Pode-se perguntar, então, quais são as interações, em um dia de escola, que favorecem o compromisso de S. na exploração e no desenvolvimento de sua competência linguística.

\subsection{Aquém e além da zona de desenvolvimento proximal ${ }^{14}$}

WILLET (1995, p.481) nota, na sala que observou, que depois de algumas semanas, um observador exterior não é mais capaz de distinguir as crianças récem-chegadas das crianças anglófonas porque "se pedia às crianças inglês segunda língua o mesmo que às crianças linguisticamente experientes: elas realizavam as mesmas tarefas, seguiam as mesmas regras e utilizavam o mesmo material". O mesmo acontece com S. No entanto, por vezes, relaxa completamente sua atenção nas interações que inflamam seus colegas, e isso porque lhe faltam conhecimentos ao mesmo tempor referenciais e linguísticos para acompanhar, nem que seja globalmente, as trocas que se desenvolvem. É assim em interações de preparação para a "aula

\footnotetext{
${ }^{13}$ Nota dos Trad. Em francês, ele não retoma a preposição A, solicitada pelo verbo DIRE. O que a autora aponta é, portanto, que S. não se apropria da estrutura sintática verificada, dizendo "Bachir disse mim" ao invés de "Bachir disse para mim".

${ }^{14}$ Lembremo-nos de que o conceito desenvolvido por VYGOTSKI é definido como o que a criança "sabe fazer hoje em colaboração" e que ele "saberá fazer amanhã sozinho". Esta zona, que "determina as possibilidades de aprendizagem" (VYGOTSKI, 1997, p.355-356), é delimitada por um limite inferior (abaixo do qual se encontra o que a criança sabe fazer sozinha) e um limite superior, para além do qual se encontra o que a criança não pode ainda fazer, mesmo com a ajuda de um adulto.
}

Olh@res, Guarulhos, v. 1, n. 2, p. 100-119, Novembro, 2013. 
verde" 15 ou de preparação de um encontro esportivo inter-escolas. Durante essas interações, S. parece "sonhar". O contraste é importante com as atividades rituais, das quais, como já dissemos, S. participa ativamente. Ao final do ano escolar, ele está, inclusive, mais atuante do que alguns colegas para o ritual da data, que consiste em dizer, em um formato de frase imposta, a data do dia anterior, a data do dia e a data do dia seguinte. Se a aprendizagem dessas frases provavelmente contribuíram, nos primeiros meses, para o armazenamento de "expressões modelos" que são conhecidas como uma das fases de aquisição em crianças, parece bem que, no final do ano, sua participação entusiasta nestas atividades não tem mais do que uma função socializante.

Entre as interações que estão para além de sua capacidade de linguagem, porque as temáticas desenvolvidas são muito desconectadas do contexto imediato ou dos temas recorrentes da aula e as interações altamente ritualizadas que, ao final do ano letivo, só solicitam de $\mathrm{S}$. intervenções localizadas abaixo de sua zona de desenvolvimento proximal, há toda uma gama de interações que lhe permitem explorar os micro-sistemas de sua interlíngua.

\subsection{As interações de jogo}

Quando eles terminaram uma atividade e a professora está ocupada com alunos de $\mathrm{CE} 1^{16}$, os alunos de $\mathrm{CP}$ têm o direito de brincar com jogos de tabuleiro. S. frequentemente toma a iniciativa de propor partidas de xadrez ou de outros jogos do tipo dominó. Essas situações regradas, em que os desafios são imediatos, ao mesmo tempo reais e limitados, constituem um espaço propício às atividades linguageiras de apropriação. Assim, em 20 de junho, quando sua colega come seu peão em uma partida de xadrez dizendo "Eh, bem,

\footnotetext{
${ }^{15}$ Nota dos Trad. A "aula verde" (classe verte) é uma saída escolar durante a qual os alunos partem em descoberta da natureza sem os pais, mas acompanhados pelos professores.

${ }^{16}$ Nota dos Trad. Sigla para Curso Elementar primeiro ano. Vem logo após o CP.

Olh@res, Guarulhos, v. 1, n. 2, p. 100-119, Novembro, 2013.
} 
tchau tchau", ele, por sua vez, come uma peça repetindo o que se apropriou da expressão: "Eh tchau tchau tchau". Muitas vezes, instalando seus peões brancos (sua cor favorita) para uma partida de xadrez, ele comenta a ausência de um peão que foi substituído, na caixa, por um peão diferente daqueles do jogo, já que de cor preta. Em 30 de março, ele disse colocando o peão no tabuleiro: "não é branco" $"$. Em 01 de junho, ele participou de um jogo de cartas com Amal que tenta, em vão, fazer com que $\mathrm{S}$. baixe, de suas cartas, as que tinham um pequeno logotipo com uma casa vermelha. Ela lhe pergunta se ele tem ainda cartas como essa, lembrando-lhe que ela baixou uma, e enfatiza o fato de que ela mesma não tem mais cartas assim e que ele, certamente, tem outras. S. está disposto a admitir que tem cartas com casas, mas não com "casas vermelhas".

\section{Recorte 2: Jogo, tempo livre - 01 de junho}

1. A.: eu, eu não tenho mais com esse negocinho vermelho embaixo

2. S.: X

3. A.: $\mathrm{X}$ casa casinhas vermelhas embaixo aqui, você, você tem muitas. Você sabe $\mathrm{X}$ (quantas?) Eu estou vendo aqui. Tem casinhas vermelhas.

4. S.: Aqui tem casinhas vermelhas isso isso isso

5. A.: olhe as casinhas vermelhas

6. S.: Sim, mas eu não tenho vermelha, eu aqui

7. A.: Eu só tenho uma

8. S.: < olha uma a uma suas cartas tranquilamente > mas isso, uh, não é + vermelho + vermelho + isso não é vermelho + isso não é vermelho + isso isso não é vermelho + isso não é vermelho + isso não é vermelho.

Além da repetição no turno 4, que talvez seja a manifestação de algo que foi compreendido, parece interessante nos atermos na série de auto-retomadas na intervenção 8. A auto-reformulação que intervém é muito marcante, pois corresponde a uma modificação para se obter maior conformidade com a norma linguística e não deixa de lembrar o auto-apoio mencionado por Pallotti (2005, p.115). Deve-se notar, porém, que nada na entonação sugere um trabalho de auto-reparação. Nada permite afirmar que o reajustamento em direção à

\footnotetext{
${ }^{17}$ Nota dos Trad. Vale observar que, em francês, o que S. disse foi "est pas blanc", quando deveria ter colocado, no enunciado, o pronome Il diante do verbo (Il est pas blanc).

Olh@res, Guarulhos, v. 1, n. 2, p. 100-119, Novembro, 2013.
} 
norma linguística é fruto de um trabalho consciente, mas esses três recortes, dentre muitos outros que podemos mencionar, atestam uma atividade de linguagem intensa durante os momentos de jogo. Poderíamos aproximar essas sequências de outras passagens de interações bastante lúdicas em que $\mathrm{S}$. parece explorar as zonas instáveis de sua interlíngua.

Em 23 de março, S., organizando-se para a recreação, disse com satisfação "biblioteca minha + + biblioteca". Ele evoca, assim, para si, a pequena biblioteca de 14 livros, denominada assim pela professora, que esta lhe fez fazer ao lado de sua mesa durante a correção coletiva de um problema de matemática, em que era preciso subtrair 5 livros de 14 livros. Em 30 de março, é o dia de S. cuidar da organização da aula. Cada uma das tarefas que lhe são atribuídas torna-se uma oportunidade para uma atividade de linguagem. Antes de colocar uma folha na frente de cada um de seus colegas, ele disse "uma folha" (às vezes, acompanhado do nome do colega). Em outra distribuição, deixa a si mesmo por último e diz, em tom de brincadeira, algo que se aproxima de "quem é que não tem $\lambda$ ". Depois, repete a mesma fala, aproximando-se da mesa da professora para colocar a última folha. Um pouco mais tarde, na mesma manhã, ele recolhe os cadernos e pronuncia, a cada vez, o nome da criança (o que não é usual). Quando chega nele mesmo, diz teatralmente "e eu"18.

O que é comum a estas intervenções linguísticas, além de serem uma oportunidade para S. explorar diferentes formas de ancoragem enunciativa se apoiando nas marcas de primeira pessoa, é sua natureza não-necessária, quase gratuíta e, portanto, não arriscada. Podemos considerar essas produções de linguagem como fala

\footnotetext{
${ }^{18}$ Ficamos tentados em aproximar estes enunciados do comentário que S. fez no mesmo dia enquanto começou um jogo de construção com Amal (que, no início, não era para ser um jogo competitivo). Uma primeira vez, ele declara "pronto" seguido rapidamente por "eu terminado" [Nota dos Trad. Em francês, ele diz ma fini, o que remeteria ao moi fini]. Depois, mostrando as duas construções: "você segundo, eu primeiro" [Nota dos Trad. Aqui, uma vez mais, ele diz ma premier]. Estes enunciados aproximam-se dos precedentes do ponto de vista dos micro-sistemas da interlíngua explorados, mesmo se se afastam destes mesmos enunciados pelo fato de que têm um destinatário evidente.
}

Olh@res, Guarulhos, v. 1, n. 2, p. 100-119, Novembro, 2013. 
egocêntrica, mesmo se elas não têm um destinatário evidente. Com efeito, o simples fato de que ocorrem em francês mostra que participam de uma prática de linguagem social. Certo, nada garante que essas práticas de linguagem permitirão uma aproximação da competência linguística de S. da dos falantes nativos, mas é difícil não ver nesta relação gratuíta, lúdica, à língua, e, ao mesmo tempo, muito focada em termos de micro-sistemas postos em prática, algo semelhante a uma estratégia de aprendizagem. Vê-se, portanto, que a análise dos vínculos entre estratégias de aprendizagem e estratégias de comunicação que apresentava o fato de se "assumirem riscos" como "uma condição necessária para que o locutor não-nativo se torne um candidato aprendente" (BANGE, 1992, p.67) deve ser minimizada.

\subsection{A exploração sistemática dos empregos de um item}

Em um contexto menos lúdico, com desafios comunicativos imediatos, mas de modo igualmente (se não mais) sistemático, $\mathrm{S}$. explora os empregos possíveis da expressão "ou o quê" ( $c f$. recortes 3 e 4 infra, 08 e 09 de junho). Essas três ocorrências próximas de "ou o quê" nos mostra, de um lado, que ele identificou corretamente a expressão e que é capaz de reconstitui-la, de outro, que as condições de emprego dessa expressão não estão claramente fixadas, já que, apenas na intervenção 1 do recorte 3 , ela é de fato conforme a um emprego de um falante nativo.

Olh@res, Guarulhos, v. 1, n. 2, p. 100-119, Novembro, 2013. 


\section{Recorte 3: Preparação para "aula verde" - 08 de junho}

$<$ S tenta atrair a atenção de sua vizinha concentrada em um caderno. Ele a chama>

1. S.: Amal Amal Amal você não me entende $\pi \square$ Você não me entende ${ }^{19} \lambda$ Você não me entende ou o quêr

$<$ Alguns minutos mais tarde: S. se voltou para uma colega sentada atrás dele. A professora fez a chamada e, quando chega em seu sobrenome, insiste nele.>

2. S.: Sim disse $\operatorname{sim}=$

3. P.: = Tudo bem, mas eu estou te chamando também para que + você se +

4. A.: vire

(...)

7. S.: Por quê

8. P.: Porque na sala, $\mathrm{S}$. lembra para mim a regra

9. S.: trabalho ou o quê

10. P.: Nós trabalhamos, sim

\section{Recorte 4: Correções - 09 de junho}

Os alunos trabalham sozinhos, enquanto P. verifica os papéis para a aula verde.

$\mathbf{S}$ <para os colegas próximos ou para si mesmo> "eu, eu terminei ou o quê".

Poderíamos simplesmente concluir que há uma sobregeneralização do emprego de "ou o que", ao qual S. parece atribuir uma função comunicativa bastante ampla, próxima daquela de "não é". No entanto, S. usa três vezes a expressão em três horas de gravação feita nesses dois dias, misturando momentos em que efetivamente se arrisca (particularmente na intervenção 10 do recorte 2, em que os riscos não são apenas da ordem do malentendido) e a exploração mais mais próxima das formas de linguagem quase que auto-dirigidas evocadas em 2.2. Isto nos convida a concluir que há um "trabalho" sistemático de tipo estratégico.

\footnotetext{
${ }^{19}$ A entonação e o contexto permitem fazer a hipótese que ele quer lhe perguntar se ela o compreende.

Olh@res, Guarulhos, v. 1, n. 2, p. 100-119, Novembro, 2013.
} 


\section{Quando o papel de aluno e o papel de aprendiz de língua se} encontram: as identidades reconciliadas

Mostramos alguns aspectos das dificuldades que S. encontrava para assumir seu estatuto de aluno plurilíngue (negação de sua competência em albanês). Fizemos a hipótese de que esta recusa era devida provavelmente ao fato de que seu estatuto de aluno plurilíngue convocava, sem dúvida, a seus olhos de maneira imperiosa, uma outra dimensão de sua identidade que ele não queria ver tematizada nas interações, a saber, a de aluno não-francófono, de aluno aprendiz de francês, de aluno menos experiente em francês. Vimos também que essas negações não impediam S. de desenvolver sua competência linguística em francês e estudamos alguns dos lugares interacionais que parecem contribuir para suas aprendizagens linguísticas. Gostaríamos de terminar este estudo com um recorte da gravação coletada durante a nossa penúltima visita.

Neste dia, foi Bachir, figura importante do grupo de alunos de CE1, o responsável por ler o cardápio. Após oito interações para ajudar Bachir a ler a palavra "rilletes" 20 K. intervém, interrompendo a professora:

\section{Extrato 5: Leitura do menu - 08 de junho de 2006 -}

1. K.: eu eu sei o que o que é "rillette"

2. S.: eu não, eu não + + eu não

3. As + P.: <brouhaha>

4. P.: Ao mesmo tempo que Bachir fala, vocês escutam também einh?

5. S. Eu não $\lambda \mathrm{Eu}$

6. P.: você sabe o que é "rillettes" =

7. $\mathrm{S} .:=$ não

\footnotetext{
20 Nota dos Trad. Especialidade francesa que se assemelha a um patê com carne em pedaços, feito de carne de porco ou outros tipos de carne, misturadas ou não.

Olh@res, Guarulhos, v. 1, n. 2, p. 100-119, Novembro, 2013.
} 
A intervenção de K. em 1, que categoriza uma parte da sala - em todo caso, categoriza Bachir ${ }^{21}$ - como não sabendo o que são "rillettes", permite a $S$. de se categorizar, por sua vez, como não sabendo também o que é isso (eu não repetido três vezes). Certo, há uma ambiguidade nesta passagem sobre o que é desconhecido para os alunos (a palavra e/ou seu referente), mas é notável que S. aproveite desta ambiguidade para dizer, pela primeira vez em nosso corpus, que não conhece uma palavra. Saber dizer que não sabemos faz parte das competências do papel do aluno e é muito mais fácil "confessar" quando se vê que não se está sozinho. Neste contexto particular, que intervém no mês de junho, S., que adquiriu uma certa segurança linguística, parece encontrar um meio de conciliar a sua identidade de aluno da sala de CP-CE1 e sua identidade de aprendiz de língua.

Construir seu lugar nas interações de uma sala de alunos francófonos, quando se é o único aluno alófono, certamente não é uma tarefa fácil. A frequentação assídua em cursos específicos para alunos nãofrancófonos permite se categorizar legitimamente como "aprendiz de língua”, perceber seu avanço - graças, sobretudo, à chegada de outros alunos iniciantes em francês - e se envolver em intervenções de maior duração. Tudo isso se deve ao ambiente específico dessa classe, ao mesmo tempo mais "seguro" e mais aberto às conquistas metalinguísticas do que o de uma classe regular.

O estudo das interações em classes regulares revela, no entanto, múltiplas ocasiões para a criança alófona de conjugar aprendizagens escolares, socialização escolar e socialização linguística. A riqueza da articulação entre essas diferentes formas de engajamentos na interação delineada por este estudo convida a continuar a observação deste modo de integração escolar das crianças recém-chegadas.

\footnotetext{
${ }^{21}$ É possível que o fato de Bachir não comer carne de porco nas refeições contribua para a reação de K., que supõe, talvez, existir um vínculo entre esta prática alimentar e o desconhecimento desse alimento.

Olh@res, Guarulhos, v. 1, n. 2, p. 100-119, Novembro, 2013.
} 
O aluno com pouco domínio na língua da escolarização: convergência ou concorrência da socialização linguageira e da socialização escolar?

\section{Referências bibliográficas}

ARDITTY, Jo . Approches interactionnistes : exemples de fondements théoriques et questions de recherche, Le Français dans le Monde, Recherches et Application, Les interactions en classe de langue, 2005.

BANGE, Pierre. A propos de la communication et de l'apprentissage en L2, notamment dans ses formes institutionnelles, AILE 1, 53-58, 1992.

GAJO, Laurent et MONDADA, Lorenza. Interactions et acquisitions en contexte, Fribourg, Editions universitaires de Fribourg, 2000.

PALLOTTI, Gabriele. Variations situationnelles dans la construction des énoncés en L2 : le cas des autorépétitions, AILE 22, Interaction et diversité des conduites d'apprentissage, 2005.

RIVIERE, Véronique. Aujourd'hui nous allons travailler sur..., Le Français dans le Monde, Recherches et Application, Les interactions en classe de langue, 2005.

VASSEUR, Marie Therèse. En CLIN, l'apprentissage du français passe par la socialisation langagière, LINX, 49, Acquisition et communication en langue étrangère: Interlangue et communication exolingue / endolingue, Nanterre, 125-140, 2003.

VYGOTSKI, Lev S. Pensée et langage, La dispute, Paris, 1997.

WILLETT, Jerri. Becoming First Graders in an L2 : An Ethnographic Study of L2 socialization, TESOL Quarterly Vol. 29, 473-503, 1995.

\section{Tradutores}

Texto traduzido por Márcia Romero (Universidade Federal de São Paulo) e Thatiana Ribeiro Vilela (Universidade Federal de São Paulo).

Olh@res, Guarulhos, v. 1, n. 2, p. 100-119, Novembro, 2013. 